

Goods, Works, Nonconsulting and Consulting Services

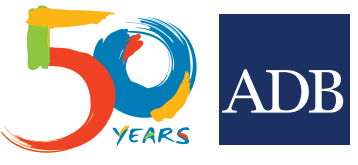




\section{PROCUREMENT REGULATIONS FOR ADB BORROWERS}

Goods, Works, Nonconsulting and Consulting Services 
(C) 2017 Asian Development Bank

6 ADB Avenue, Mandaluyong City, 1550 Metro Manila, Philippines

Tel +632632 4444; Fax +6326362444

www.adb.org

Some rights reserved. Published in 2017.

ISBN 978-92-9257-917-3 (Print), 978-92-9257-918-o (e-ISBN)

Publication Stock No. TIM178808

http://dx.doi.org/10.22617/TIM178808

ADB does not guarantee the accuracy of the data included in this publication and accepts no responsibility for any consequence of their use. The mention of specific companies or products of manufacturers does not imply that they are endorsed or recommended by ADB in preference to others of a similar nature that are not mentioned.

By making any designation of or reference to a particular territory or geographic area, or by using the term "country" in this document, ADB does not intend to make any judgments as to the legal or other status of any territory or area.

This work is available under the Creative Commons Attribution-NonCommercial-NoDerivs 3.0 IGO license (CC BY-NC-ND 3.0 IGO) http://creativecommons.org/licenses/by-nc-nd/3.0/igo/. By using the content of this publication, you agree to be bound by the terms of this license. For attribution and permissions, please read the provisions and terms of use at https:/www.adb.org/ terms-use\#openaccess

This CC license does not apply to non-ADB copyright materials in this publication. If the material is attributed to another source, please contact the copyright owner or publisher of that source for permission to reproduce it.

ADB cannot be held liable for any claims that arise as a result of your use of the material.

Please contact pubsmarketing@adb.org if you have questions or comments with respect to content, or if you wish to obtain copyright permission for your intended use that does not fall within these terms, or for permission to use the ADB logo.

Notes:

In this publication, “\$” refers to US dollars.

Corrigenda to ADB publications may be found at http://www.adb.org/publications/corrigenda 


\section{Contents}

I. Introduction 1

Purpose 1

General Considerations 2

Fitness for Purpose 3

Alternative Procurement Arrangements 4

Applicability of These Regulations 4

Procurement of Contracts Not Financed

by the Asian Development Bank 5

Eligibility 5

$\begin{array}{ll}\text { Conflict of Interest } & 7\end{array}$

Unfair Competitive Advantage $\quad 7$

Advance Contracting and Retroactive Financing 8

Asian Development Bank Review 8

Noncompliance 8

Complaints 9

Integrity 9

$\begin{array}{lr}\text { E-procurement } & 9\end{array}$

Procurement Plan 10

Procurement for Nonsovereign Operations 10

II. Procurement Methods and Arrangements 11

$\begin{array}{ll}\text { Open Competitive Bidding } & 11\end{array}$

Limited Competitive Bidding $\quad 12$

Framework Agreements $\quad 12$

Request for Quotations $\quad 13$ 
$\begin{array}{ll}\text { Electronic Reverse Auction } & 13\end{array}$

Direct Contracting 14

Force Account $\quad 15$

Particular Types of Procurement Arrangements 16

A. Selection of Consultants 16

B. Selection of Individual Consultants 16

C. Procurement from Specialized Agencies 16

D. Procurement in Fragile and Conflict-Affected Situations 17

E. Procurement Agents 17

F. Support to Governments for Public-Private Partnerships 18

G. Procurement of High-Level Technology 18

H. Performance-Based Procurement 19

I. Community Participation in Procurement 20

J. Procurement under Loans Guaranteed by the Asian Development Bank 20

Appendix 1: Value for Money 21

$\begin{array}{ll}\text { Introduction } & 21\end{array}$

Achieving Value for Money $\quad 21$

Planning for Value for Money $\quad 22$

\section{Appendix 2: Procurement Planning 24}

Appendix 3: Open Competitive Bidding Procedure 27

Type and Size of Contracts 27

Two-Stage Bidding $\quad 28$

Two-Envelope Bidding $\quad 28$

Notification and Advertising $\quad 29$

Prequalification of Bidders $\quad 30$

Joint Ventures $\quad 31$ 
Bidding Documents

Validity of Bids and Bid Security

Language

Clarity of Bidding Documents

Specifying Quality

Use of Brand Names

Pricing for Goods and Works

Price Adjustment

Transportation and Insurance

Professional Liability

Currency Provisions

Alternative Bids

Conditions of Contract

Contract Management

Performance Security

Liquidated Damages and Bonus Clauses

Force Majeure

Applicable Law and Settlement of Disputes

Time for Preparation of Bids

Bid Opening Procedures

Clarifications or Alterations of Bids $\quad 40$

Confidentiality $\quad 40$

Examination of Bids $\quad 41$

Evaluation and Comparison of Bids $\quad 41$

Evaluation Report $\quad 41$

Abnormally Low Bids $\quad 42$

Domestic Preferences $\quad 42$

Extension of Validity of Bids 43

Post Qualification of Bidders 43

Intention for Award of Contract 43 
Publication of the Award of Contract 45

Rejection of All Bids $\quad 45$

$\begin{array}{ll}\text { Debriefing } & 46\end{array}$

\section{Appendix 4: Consulting Services Selection}

Using Open Competitive Biddling $\quad 47$

$\begin{array}{ll}\text { Short-Listing } & 47\end{array}$

Selection Methods $\quad 47$

Pricing for Consulting Services 49

Evaluation Criteria and Methodology for Consulting Services 49

Appendix 5: Evaluation Criteria and Methodology 51

Key Requirements $\quad 51$

Evaluating Goods, Works, and Nonconsulting Services 52

Evaluating Consulting Services 53

\section{Appendix 6: Asian Development Bank Review} of Procurement Decisions 55

Scheduling of Procurement 55

Prior Review 56

Post Review (Sampling) $\quad 57$

Appendix 7: Bidding-Related Complaints $\quad 59$

Purpose $\quad 59$

Scope $\quad 59$

Complaint 60

Requirements for Consideration $\quad 60$

Review Process $\quad 61$

Resolution 63 
Roles and Responsibilities 64

Tracking and Reporting 65

Contract Administration $\quad 65$

Appendix 8: Contract Management 66

Appendix 9: Roles and Responsibilities in Asian Development BankFinanced Procurement

$\begin{array}{ll}\text { Purpose } & 68\end{array}$

Responsibility for Procurement 68

Roles of the Asian Development Bank 68

Information on Bidding $\quad 69$

Bidder's Role $\quad 70$

Confidentiality $\quad 70$

Actions by the Asian Development Bank 71

$\begin{array}{ll}\text { Debriefing } & 71\end{array}$ 



\section{Introduction}

\section{Purpose}

1.1 In application of the Procurement Policy of the Asian Development Bank (ADB), the purpose of these Procurement Regulations for ADB Borrowers ("Regulations") is to inform those carrying out a project that is financed in whole or in part by way of an investment loan ${ }^{1}$ from $A D B, A D B$-financed grant, ${ }^{2}$ or by ADB-administered funds of the policies and procedures that govern the procurement of goods, works, and nonconsulting and consulting services ${ }^{3}$ required for the project. The financing agreement governs the legal relationships between the borrower ${ }^{4}$ and $A D B$, and these Regulations are made applicable to procurement of goods, works, and services for the project, as provided in the agreement.

1.2 The rights and obligations of the borrower and the providers of goods, works, and services for the project are governed by the bidding documents and by the contracts signed by the borrower with providers of goods, works, and services, and not by these Regulations or the financing agreements. No party other than the parties to the financing agreement shall derive any rights therefrom or have any claim to the proceeds of the financing.

These Regulations do not apply to results-based lending or policy-based loans.

For technical assistance (TA) administered by ADB and staff consultancies, the selection, engagement, and supervision of TA grant-financed and staff consultants will be governed by the TA Staff Instructions.

3 For the purpose of these Regulations, "services" shall include both nonconsulting and consulting services unless otherwise indicated. See para. 1.12 for detailed definitions of these two terms.

4 The term "borrower" as used in these Regulations includes recipients of ADB-financed grants and ADB-administered funds, and refers to the executing agency for the ADB-financed project, in each case in the context of ADB's sovereign operations. Unless specifically stated, a borrower does not include a borrower under ADB's nonsovereign operations. In some cases, the borrower acts only as an intermediary, and the project is carried out by another agency or entity, in which case references in these Regulations to the borrower include such agencies and entities, as well as sub-borrowers under on-lending arrangements. 


\section{General Considerations}

1.3 The responsibility for the implementation of the project, and therefore for the award and administration of contracts under the project, rests with the borrower. $A D B$, for its part, has the obligation to ensure that the proceeds of its financing are used with due attention to the principles and considerations defined in these Regulations and application of risk-adjusted procurement rules that are fit for purpose.

1.4 While in practice the specific procurement rules and procedures to be followed in the implementation of a project depend on the circumstances of the case, six core procurement principles (collectively "Core Procurement Principles") guide ADB requirements:

(a) Economy: Taking into account factors such as price, quality, and any nonprice attributes as appropriate without adversely affecting the viability of the project.

(b) Efficiency: Ensuring that procurement processes are proportional to the value and risks of the required outcome and underlying project activities, taking into account of implementation capacity, time constraints, and cost-effectiveness.

(c) Fairness: Ensuring (i) equal opportunity and treatment for eligible bidders; ${ }^{5}$ (ii) equitable distribution of rights and obligations between borrowers and providers of goods, works, and services; and (iii) credible mechanisms for addressing procurementrelated complaints and providing recourse. $A D B$ encourages open competition as the preferred procurement approach whenever possible to maximize fairness of the opportunity to bid.

(d) Transparency: Through appropriate documentation and review of the procurement process activities, ensuring that (i) relevant procurement information is made publicly available to all interested parties, in a consistent and timely manner, through readily accessible and widely available sources at no (or reasonable) cost;

(ii) there is appropriate reporting of procurement activity; and (iii) confidentiality provisions in contracts are used only where justified.

For the purposes of these Regulations, a "bidder" means a natural or legal person who submits a bid, proposal, or quotation with the objective of being awarded a contract pursuant to one of the methods of procurement identified in these Regulations. A "bidder" may be a supplier of goods, a works contractor, or a provider of consultancy or nonconsultancy services. 
(e) Quality: Structuring procurement arrangements ${ }^{6}$ to procure inputs and deliver outputs of appropriate standard in a timely and effective manner to achieve the project outcomes and development objectives, taking into account the context, risk, value, and complexity of procurement.

(f) Value for money: Enabling the borrower to obtain optimal benefits through effective, efficient, and economic use of resources, by applying, as appropriate, the Core Procurement Principles and related considerations, which may include life-cycle costs and socioeconomic and environmental development objectives of the borrower. Price alone may not sufficiently represent value for money.

\section{Fitness for Purpose}

1.5 Fitness for purpose requires procurement arrangements to appropriately reflect the strategic needs and circumstances of the situation. In case a standardized approach cannot effectively and efficiently meet project outcomes and development objectives, including in capacity-constrained environments, a customized approach may be adopted, entailing transaction-specific methods and documentation. ${ }^{7}$

1.6 Open competitive bidding (OCB), properly administered and open equally to national and international bidders, is likely to result in value for money in most cases and is therefore recommended as the most appropriate method. Section II of these Regulations describes the procedures for $\mathrm{OCB}$.

1.7 In specific situations, other methods of procurement may be used. Section II of these Regulations describes these other methods and the conditions for their use.

1.8 Depending on the circumstances under which their application is deemed appropriate, ADB may accept use of alternative procurement arrangements specified in para. 1.9.

Procurement arrangements include procurement modalities and, as the context permits, the nature and extent of borrower responsibility and $A D B$ oversight.

The specific methods that may be followed for procurement under a given project are specified in the procurement plan. 


\section{Alternative Procurement Arrangements}

1.9 ADB may agree to (a) apply the procurement rules and procedures of another multilateral or bilateral agency or organization involved in the project, and may agree to such a party taking a leading role in providing implementation support and monitoring project procurement activities; or (b) rely on the procurement rules and procedures applied by an agency or entity of the borrower accredited by ADB, provided that in each case such arrangements are (i) compatible with the value, risk, or complexity of the procurement; (ii) consistent with the Core Procurement Principles; and that (iii) unless waived, ADB's member country eligibility restrictions set out in para. 1.14 continue to apply; and (iv) ADB's Anticorruption Policy and Integrity Principles and Guidelines $^{8}$ (both as amended from time to time) (hereafter ADB's Anticorruption Guidelines) and contractual remedies in applicable financing agreements with the borrower continue to apply.

1.10 For alternative procurement arrangements, ADB shall be satisfied with the assessed fiduciary risks and the established mitigation measures.

\section{Applicability of These Regulations}

1.11 These Regulations govern the procurement of goods, works, and services required by the borrower and financed in whole or in part by ADB.

1.12 The services herein consist of two types of services:

(a) consulting services which are of an intellectual and advisory nature requiring evaluation of technical proposals that offer tailored approaches, methodologies, and specially qualified experts; and

(b) nonconsulting services, which include

(i) services for which the physical aspects of the activity predominate, that are bid and contracted on the basis of performance of a measurable physical output, and for which performance standards can be clearly identified and consistently applied; or

ADB. 1998. Anticorruption Policy. Manila. https://www.adb.org/documents/anticorruption-policy and ADB. 2015. Integrity Principles and Guidelines. Manila. https://www.adb.org/documents/integrityprinciples-and-guidelines 
(ii) routine services which, while requiring expert inputs, are based on recognized standard offerings that are readily available and which do not require evaluation of tailored methodologies or techniques.

\section{Procurement of Contracts Not Financed by the Asian Development Bank}

1.13 For the procurement of those contracts for goods, works, and services not financed by ADB, the borrower may adopt other procedures.

In such cases, ADB shall be satisfied that the procedures to be used will fulfill the borrower's obligations to cause the project to be carried out diligently and efficiently and that the goods, works, and services to be procured

(a) are of satisfactory quality and are compatible with the balance of the project,

(b) will be delivered or completed in a timely manner, and

(c) are priced so as not to affect adversely the economic and financial viability of the project.

\section{Eligibility}

1.14 Except in any case in which the Board of Directors determines otherwise, (i) loans or grants from Special Funds resources can be used only for procurement of goods, works, and services produced in, and supplied from, developed member countries that have contributed to such resources, or from developing member countries; and (ii) loans or grants from ADB's ordinary capital resources or ADB-administered funds can be used only for procurement of goods, works, and services produced in, and supplied from, member countries.

1.15 To foster competition, ADB permits bidders from all eligible countries to offer goods, works, and services for ADB-financed projects. Any conditions for participation shall be limited to those that are essential to ensure the bidder's capability to fulfill the contract in question.

1.16 In connection with any contract to be financed in whole or in part by $\mathrm{ADB}$, and subject to para. 1.18, ADB does not permit a borrower to deny the participation of a bidder for reasons unrelated to its capability 
and resources to successfully perform the contract, nor does it permit a borrower to disqualify any bidder for such reasons. Consequently, borrowers should carry out due diligence on the technical and financial qualifications of bidders to be assured of their capabilities in relation to the specific contract.

1.17 Qualification requirements must be nonrestrictive and therefore be limited to those criteria which are designed to demonstrate that a bidder or group of bidders possesses the necessary professional and technical qualifications and competence, financial resources, equipment and other physical facilities, managerial capability, relevant general and specific experience, business reputation, and capacity to perform the contract. Bidders may be requested to provide evidence of qualification and experience, including past performance, and they shall submit the documents and information specified in the bidding documents along with their bids.

1.18 As exceptions to the foregoing:

(a) Bidders may be excluded if, by an act of compliance with a decision of the United Nations Security Council taken under Chapter VII of the Charter of the United Nations, the borrower's country prohibits any import of goods from, or payments to, a particular country, person, or entity in respect of goods or services originating in that country. Where the borrower's country prohibits payments to a particular firm or for particular goods by such an act of compliance, that firm may be excluded.

(b) Government-owned enterprises in the borrower's country may participate as a bidder only if specifically agreed by ADB.

(c) Without limitation to (b) above, when the services of governmentowned universities or research centers in the borrower's country are of unique and exceptional nature, and their participation is critical to project implementation, ADB may agree on the hiring of those institutions on a case-by-case basis. On the same basis, staff from universities or research centers can be contracted individually under ADB financing.

(d) Government officials and civil servants in the borrower's country may only be hired under consulting contracts, either as individuals or as members of a team of a consulting firm, if they

(i) are not being hired by the agency they were working for immediately before going on leave, and

(ii) their employment would not create a conflict of interest. 
(e) A firm or individual sanctioned or temporarily suspended by ADB in accordance with ADB's Anticorruption Guidelines shall be ineligible to participate in or to be awarded an $A D B$-financed or ADB-administered contract or to benefit from an ADB-financed or $A D B$-administered contract, financially or otherwise, during the period of time determined by ADB.

\section{Conflict of Interest}

1.19 ADB considers a conflict of interest to be a situation in which a party has interests that could improperly influence that party's performance of official duties or responsibilities, contractual obligations, or compliance with applicable laws and regulation. A conflict of interest may not, in all cases, in and of itself, constitute a violation of ADB's Anticorruption Guidelines, if appropriately addressed or mitigated.

1.20 ADB requires bidders to disclose all conflicts of interest during the bid submission. ADB will take appropriate actions to manage such conflicts of interest or may reject a proposal for award if it determines that a conflict of interest has flawed the integrity of any procurement process.

1.21 ADB requires that all those who are involved in the procurement process for an ADB-financed contract (i) do not have a conflict of interest with regard to the procurement concerned and are required to remain professional, objective, and impartial; and (ii) are required to always hold the borrower's interest paramount, without any consideration of future work, and to avoid conflicts with other assignments and their own corporate and personal interests.

\section{Unfair Competitive Advantage}

1.22 Fairness and transparency in procurement require that bidders competing for a specific contract do not derive any unfair competitive advantage from having provided goods or services related to the contract in question. To that end, $\mathrm{ADB}$ or the borrower shall make all information that would give a bidder or consultant an unfair competitive advantage available to all prospective bidders or consultants. 


\section{Advance Contracting and Retroactive Financing}

1.23 If a borrower proceeds with the initial steps of procurement before signing the related financing agreement, the procurement procedures, including advertising, shall be acceptable to ADB in accordance with these Regulations for any contracts subsequently awarded to be eligible for ADB financing.

1.24 A borrower undertakes such advance contracting at its own risk. Any concurrence by ADB with the procedures, documentation, or proposal for award does not commit $A D B$ to finance the project in question.

1.25 If the contract is signed, reimbursement by ADB of any expenses incurred by the borrower under the contract prior to effectiveness of the financing agreement is referred to as retroactive financing.

\section{Asian Development Bank Review}

1.26 ADB reviews the borrower's procurement procedures, documents, bid evaluations, award recommendations, and contracts under a risk-based approach through prior and post review (sampling) to ensure that the procurement process is carried out in accordance with the agreed procedures.

1.27 ADB may, where necessary, provide extended support without however diminishing the responsibility of the borrower for the execution of the procurement or becoming involved in the procurement decisionmaking process (or a part thereof).

1.28 ADB review procedures are described in Appendix 6. The procurement plan approved by $A D B$ shall specify the extent to which these review procedures shall apply in respect of the different categories of goods, works, and services to be financed, in whole or in part, by ADB.

\section{Noncompliance}

1.29 Noncompliance refers to instances when the borrower or other parties involved in the procurement process fail to follow the provisions of these Regulations, including the applicable procurement requirements. 
1.30 In such cases, ADB may, in addition to exercising the contractual remedies set out in the relevant financing agreement (such as loan suspension, followed by cancellation of the loan and acceleration of loan maturity), take appropriate actions consistent with its implementation support and fiduciary role.

\section{Complaints}

1.31 Procurement-related complaints with regard to a bidding process may be brought to the attention of the borrower or ADB, or both, at the appropriate stage of the procurement process. Such complaints must be addressed objectively and in a timely manner, with transparency and fairness.

1.32 Guidance on the complaints procedure during bidding is provided in Appendix 7.

\section{Integrity}

1.33 Borrowers and any other party to a financing agreement shall always act in accordance with the highest standard of ethics during any procurement process subject to these Regulations and any use of funds, resources, assets, and authority by such parties shall be in accordance with ADB's Anticorruption Guidelines.

\section{E-procurement}

1.34 To facilitate transparency and efficiency in the procurement process, ADB encourages borrowers to continually modernize their procurement systems including procurement through electronic means (e-procurement).

1.35 E-procurement tools are recommended for communications with bidders, advertisements, notices and amendments, distribution of procurement documents, submission of bids or proposals, and disclosure of contract awards. These arrangements should be adequate, efficient, and secured, and should not prevent participation of potential bidders. 
1.36 Any e-procurement system used for ADB-financed transactions shall be accessible and secure, ensure integrity and confidentiality, and have sufficient audit trail features.

\section{Procurement Plan}

1.37 The borrower develops a procurement plan for each project describing how the procurement activities support the development objectives of the project and deliver value for money under a risk-managed approach.

1.38 The plan provides adequate justification for the procurement methods selected and gives early information to potential bidders of the upcoming procurement opportunities. This is further described in Appendix 2.

\section{Procurement for Nonsovereign Operations}

1.39 Where goods, works, or services are procured under contracts to be financed under ADB's nonsovereign operations from the proceeds of (i) an ADB loan, (ii) a loan guaranteed by ADB or (iii) a grant to a private sector recipient, the nonsovereign borrower or, as the case may be, recipient of $A D B$ grant shall use appropriate procurement methods that ensure value for money on the basis of acceptable private sector or commercial practices and the utilization of the proceeds of such loan or grant shall be subject to the eligibility criteria set out in para. 1.14 and the integrity requirements set out in para. 1.33 . 


\section{Procurement Methods and Arrangements}

\section{Open Competitive Bidding}

2.1 Open competitive bidding (OCB) is the preferred method of procurement under procurement financed by the Asian Development Bank (ADB).

2.2 The objective of $O C B$, as described in these Regulations, is to achieve value for money. This is ensured by seeking bids from qualified bidders that meet the quality and technical requirements of the borrower, timely and adequate notification of a borrower's requirements to all eligible prospective bidders, and an equal opportunity to bid.

2.3 OCB applies to the procurement of goods, works, and services. The procedures to be followed and the standard bidding documents to be applied will depend on the nature of the procurement in question. These procedures are explained in Appendixes 3 and 4.

2.4 The key steps in the OCB method are as follows:

(a) Determination of the type and size of contracts based on the circumstances and taking into account of the various elements of goods, works, and services required.

(b) Identification of the technical requirements or terms of reference and the definition of the quality and performance levels to be achieved.

(c) Application of appropriate bidder qualification criteria.

(d) Choice of procurement method, including any specific procedural requirements (such as use of two-stage or two-envelope bidding).

(e) Preparation of bidding documents and publication of procurement notices.

(f) Selection of most appropriate evaluation criteria depending on the quality and cost factors to be applied. 
(g) Notification of bid submission and bid opening procedures.

(h) Contract award procedures, including debriefing.

(i) Contract management

2.5 Depending on the context, ADB may permit other methods and arrangements not identified in these Regulations provided they are consistent with the Core Procurement Principles referred to in para. 1.4 , the eligibility requirements set out in para. 1.14, and integrity requirements mentioned in para. 1.33 of these Regulations. Justification for and means of implementing such methods or arrangements shall be included in the procurement plan.

\section{Limited Competitive Bidding}

2.6 Limited competitive bidding (LCB) is essentially OCB by direct invitation without open advertisement. It may be an appropriate method of procurement for goods, works, and services where

(a) there is only a limited number of potential bidders,

(b) the amount of the contract is not large enough to attract sufficient bidders through $\mathrm{OCB}$, or

(c) there are other exceptional reasons that may justify departure from open advertisement.

2.7 Under LCB, borrowers shall seek bids from a broad list of potential bidders to assure competitive prices. The list generally includes all potential bidders when only a limited number have been identified. In all respects other than advertisement and preferences, OCB procedures shall apply, including the notifications and publication of the award of contract.

\section{Framework Agreements}

2.8 A framework agreement (FA) means an agreement awarded pursuant to one of the methods set out in these Regulations between one or more contracting authorities and one or more contractors, suppliers, or service providers. ${ }^{9}$ The purpose of the agreement is to establish

"Service provider" in the context of framework agreements includes consultants, unless otherwise indicated. 
the terms governing contracts to be awarded during a given period, in particular with regard to price and, where appropriate, the quantity envisaged.

2.9 The FA also sets out terms and conditions under which specific procurements or service provisions ("call-offs") can be made throughout the term of the agreement.

\section{Request for Quotations}

2.10 Request for Quotations (RFQ) is a procurement method based on comparing price quotations obtained from several suppliers (in the case of goods), from several service providers (in the case of services), or from several contractors (in the case of civil works).

2.11 RFQ is an appropriate method for procuring readily available goods, standard-specification commodities of small value, standard or routine services, or simple civil works of small value.

2.12 RFQ shall indicate the description and quantity of the goods, a description of the services or specifications of works, as well as desired delivery (or completion) time and place.

2.13 Quotations may be submitted by electronic means, letter, or facsimile. The evaluation of quotations shall follow the same principles as for open bidding. The terms of the accepted offer shall be incorporated in a purchase order or brief contract.

\section{Electronic Reverse Auction}

2.14 An electronic reverse auction (e-auction) is a scheduled online event in which prequalified bidders bid against each other through the presentation of new prices, revised downwards. It is used for procurement of standardized products or services when the technical specifications or the requirements can be established with precision.

2.15 The e-auction is a particular application of a request for quotations procedure in which all bidders (that have been prequalified against the nonprice award criteria set out in the bidding documents) are invited promptly after prequalification to participate in the online auction using, as of the specified date and time, the website identified in the invitation. 
2.16 The invitation shall also set out the automated evaluation method that will be used to rank bidders during the e-auction and any other relevant information on how the e-auction is to be conducted.

\section{Direct Contracting}

2.17 Direct contracting is contracting without competition (also referred to as single source selection) and may be an appropriate method under special circumstances, such as the following:

(a) Additional items are required under an existing contract which was awarded in accordance with competitive procedures.

ADB shall be satisfied in such cases that no better offer is likely to be received, and that the price to be paid is not more than the original price. Usually, the repeat order shall occur within 18 months of the original order, with the additional quantities not normally exceeding $30 \%$ of the original quantities.

(b) Standardization of equipment or spare parts compatible with existing equipment may justify additional purchases from the original supplier. For such purchases to be justified, the original equipment shall be suitable, the number of new items shall generally be less than the existing number, the price shall be reasonable, and the advantages of another make or source of equipment shall have been considered and rejected on grounds acceptable to ADB.

(c) The required equipment is proprietary and obtainable only from one source or, in the case of consulting services, where only one firm is qualified or has experience of exceptional worth for the assignment.

(d) The contractor responsible for a process design requires the purchase of critical items from a particular supplier as a condition of a performance guarantee.

(e) Where civil works or nonconsulting services ${ }^{10}$ are to be contracted and are a natural extension of an earlier or ongoing job that was 
awarded following a competitive process, ${ }^{11}$ and it can be shown that the engagement of the same contractor will be more economical and will ensure compatibility of results in terms of quality of work.

(f) For consulting services tasks that represent a natural continuation of previous work carried out by the consultant firm and only where continuity for downstream work is essential (e.g., continuity in the technical approach, experience acquired, and continued professional liability of the same consultant) and presents a clear advantage over renewed competition.

(g) For very small consultancy assignments. ${ }^{12}$

(h) In exceptional cases, such as in response to natural disasters. ${ }^{13}$

2.18 After the contract is signed, the borrower shall publish in an English language newspaper or in English on a publicly and freely accessible website the name of the provider of the goods, works, or services, and the price, duration, and summary scope of the contract. This publication may be done quarterly and in the format of a summarized table covering the previous period.

\section{Force Account}

2.19 Force account, i.e., construction by the use of the borrower's own personnel and equipment, ${ }^{14}$ may be the only practical method for constructing some kinds of works. The use of force account may be justified where

(a) quantities of work involved cannot be defined in advance,

(b) works are small and scattered or in remote locations for which qualified construction firms are unlikely to bid at reasonable prices,

(c) work is required to be carried out without disrupting ongoing operations,

11 If the initial assignment was not awarded on a competitive basis, or if the downstream assignment is substantially larger in value, a competitive process acceptable to ADB shall normally be followed.

12 Dollar thresholds defining "very small" shall be determined in each case, with agreement of ADB and taking into account the nature and complexity of the assignment, but shall generally not exceed $\$ 100,000$.

13 Direct contracting with providers of goods, works, and services under existing loans or grants will be allowed for new contracts, with rates negotiated around those in effect for the existing contract with adjustments as required for inflation and physical considerations. Providers of goods, works, and services competitively selected under similar projects financed by other donors will be considered for direct contracting for new ADB-financed contracts.

14 Any construction unit that is majority-owned by the government, and therefore deemed dependent, shall be considered a force account unit. Force account is otherwise known as direct labor, departmental forces, or direct work. 
(d) risks of unavoidable work interruption are better borne by the borrower than by a contractor, or

(e) there are emergencies needing prompt attention.

\section{Particular Types of Procurement Arrangements}

\section{A. Selection of Consultants}

2.20 In the case of consulting services, OCB allows for methods of evaluation and comparison of bids to take account of both quality and cost according to the specific nature of the consulting services to be acquired and the conditions under which they are to be acquired (Appendix 4). In practice, this means that borrowers may

(a) balance the quality and cost of the proposed services using a quality- and cost-based selection (QCBS);

(b) prioritize quality through quality-based selection (QBS) or selection based on consultants' qualifications (CQS);

(c) select the highest quality consultant within the available budget using a fixed-budget selection (FBS); or

(d) prioritize cost through least-cost selection (LCS).

\section{B. Selection of Individual Consultants}

2.21 For certain assignments, individual consultants may be more appropriate and cost-effective than firms. Individual consultants may be recruited by the borrower directly in their individual capacity or through an organization such as a consulting firm, an academic institution, a government, or an international agency.

\section{Procurement from Specialized Agencies}

2.22 There may be situations in which procurement directly from specialized agencies, ${ }^{15}$ acting as suppliers, pursuant to their own procedures, may be the most appropriate way of procuring

\footnotetext{
Specialized Agencies are legally independent international organizations with their own rules, membership, organs, and financial resources that were brought into relationship with the United Nations through negotiated agreements. As described at United Nations System Chief Executives Board for Coordination. 2016. Directory Of United Nations System Organizations. http://www. unsystem.org/members/specialized-agencies
} 
(a) off-the-shelf goods in small quantities, primarily in the fields of education and health; and

(b) specialized products where the number of suppliers is limited, such as for vaccines or drugs.

\section{Procurement in Fragile and Conflict-Affected Situations}

2.23 In cases of Fragile and Conflict-Affected Situations (FCAS) ${ }^{16}$ where the borrower is deemed by ADB to have urgent need of assistance because of

(a) emergency situations like a natural or human-made disaster or conflict, or

(b) capacity constraints arising from fragility or specific vulnerabilities (including small states),

ADB may accept the use of appropriate procurement arrangements in accordance with the relevant provisions of these Procurement Regulations or other suitable procedures that facilitate more responsive mobilization.

\section{E. Procurement Agents}

2.24 Where borrowers lack the necessary organization, resources, and experience, borrowers may wish (or be required by ADB) to employ, as their agent, a firm specializing in handling procurement. The agent shall follow all the procurement procedures provided for in the financing agreement and the Regulations. This also applies in cases where United Nations agencies act as procurement agents. Management contractors may be employed in a similar manner for a fee to contract for miscellaneous works involving reconstruction, repairs, rehabilitation, and new construction in emergency situations, or where large numbers of small contracts are involved.

2012. ADB. Working Differently in Fragile and Conflict-Affected Situations: The ADB Experience. Manila. https://www.adb.org/documents/working-differently-fragile-and-conflict-affected-situations-adbexperience 


\section{F. Support to Governments for Public-Private Partnerships}

2.25 Where ADB provides financing support to a borrower in respect of a Public-Private Partnership (PPP), ${ }^{17}$ the procurement procedures to select the relevant contractor shall

(a) be transparent and competitive;

(b) include several stages to arrive at the optimal combination of criteria for the purpose of establishing the most economic and efficient proposal which provides value for money;

(c) be compliant with ADB's Core Procurement Principles, the eligibility criteria set out in para. 1.14 and the integrity requirements set out in para. 1.33; and

(d) ensure an appropriate allocation of risk.

2.26 ADB may, in exceptional circumstances, agree to finance a PPP arising from an unsolicited proposal provided that the process to assess and determine the best fitness for purpose and value for money approach to awarding the contract is clearly defined by the borrower and agreed with ADB.

\section{G. Procurement of High-Level Technology}

2.27 The procurement of high-level technology involves proven or advanced new technology that improves the quality of the service delivered.

2.28 The quality requirements of the infrastructure, equipment, or services to be procured are critical in such cases and may outweigh an evaluation of bids based exclusively on cost.

2.29 For particularly complex or sophisticated infrastructure, equipment, or nonconsulting services, alternative methods of procurement, such as two-stage bidding or evaluation criteria which prioritize nonprice criteria, may be appropriate to provide optimal value for money and fitness for purpose, as detailed in Appendix 5.

For consultancy services, this may be done through appropriate weighting of cost ratios under QCBS methods as detailed in Appendix 5 , or other methods of evaluation.

17 A PPP is a long-term contract between a private party and a borrower for providing a public asset or service, in which the private party bears significant risk and management responsibly and remuneration is linked to performance. PPP projects include build-own-operate (BOO), build-operate-transfer (BOT), build-own-operate-transfer (BOOT), concessions, or any similar arrangement. 


\section{H. Performance-Based Procurement}

2.30 Performance-based procurement, ${ }^{18}$ also called output-based procurement, refers to competitive procurement processes resulting in a contractual relationship where payments are made for completion of specific or discrete performance-related outputs instead of payments being made based on inputs provided.

2.31 The technical specifications define the desired result and those outputs or deliverables against which performance will be measured and payments will be made. Those outputs aim at satisfying a functional need in terms of quality, quantity, and reliability.

2.32 Payment is made in accordance with the quantity of outputs delivered, subject to their delivery at the level of quality required. Reductions from payments (or retentions) may be made for lower quality outputs and, in certain cases, premiums may be paid for higher quality outputs.

2.33 The bidding documents do not normally prescribe the inputs or work methods for the contractor or service provider. The contractor or service provider is free to propose the most appropriate solution, based on a well-grounded understanding of the desired result, and shall demonstrate that the level of quality specified in the bidding documents will be achieved.

2.34 Performance or output-based procurement can involve

(a) the provision of services to be paid on the basis of outputs;

(b) design, supply, construction or rehabilitation, and commissioning of a facility to be operated by the borrower; or

(c) design, supply, and construction (or rehabilitation) of a facility and provision of services for its operation and maintenance for a defined period of years after its commissioning.

2.35 For the cases where design, supply, and/or construction are required, prequalification is normally required and the use of two-stage bidding typically applies.

18 The use of performance-based procurement in ADB-financed projects should be the result of the satisfactory technical analysis of the different options available and should be either included in the relevant procurement plan or subject to prior no-objection by ADB. 


\section{Community Participation in Procurement}

2.36 Where, in the interest of project sustainability or to achieve certain specific social objectives of the project, it is desirable under selected project components to call for the participation of local communities and/or nongovernment organizations in the delivery of services, the procurement procedures, specifications, and contract packaging shall be suitably adapted to reflect these considerations, provided these are efficient and result in value for money.

\section{J. Procurement under Loans Guaranteed} by the Asian Development Bank

2.37 If, subject to a sovereign guarantee, ADB guarantees the repayment of a loan made by another lender, the goods, works, and services financed by such loan shall be procured in accordance with the requirements of paras. $1.4,1.13,1.14$, and 1.33 . 


\section{APPENDIX 1 \\ Value for Money}

\section{Introduction}

1. Value for money in procurement is the result of a cost-benefit analysis applied to a specific set of risks which are dependent on country context and the objectives being sought through the procurement.

2. The factors to be taken into account in this analysis are various and can be complex, making it critical to ensure that the determining factors are identified and considered at the time of preparing the procurement plan. Reconsideration and reappraisal of those factors may be required at all stages of the procurement process to guarantee value for money.

\section{Achieving Value for Money}

3. Achieving value for money through the effective, efficient, and economic use of resources requires the evaluation of relevant costs and benefits (based on the objectives sought), along with an assessment of risks and nonprice attributes and/or life cycle costs, as appropriate. Price alone may not sufficiently represent value for money.

4. Value for money may be achieved through

(a) a clear statement of the procurement needs and objectives, including permitted socioeconomic or environmental goals, if any;

(b) a procurement method that is proportional to the risk, value, context, and strategic importance of the procurement, i.e., making the process fit for purpose;

(c) adequate specification of technical requirements and of the cost and noncost elements that will need to be evaluated to achieve those requirements, including on a life cycle basis where appropriate; 
(d) selection of a contractual form that is appropriate for the objectives;

(e) clear evaluation criteria that are aligned with the needs and objectives;

(f) selection of the bidder whose bid best meets the needs and objectives; and

(g) the development of effective contract management to assure a successful implementation of the contract and that the deliverables are met as agreed in the contract.

5. Life cycle costing is generally a factor in assessing value for money.

\section{Planning for Value for Money}

6. Establishing an appropriate procurement plan defining the needs and objectives of the procurement is critical to achieving value for money. This can be achieved by designing the procurement process in a way that expresses how the purchaser will spend allocated funding to yield the most value.

7. The plan will need to take into account of the existing market and its capacity to respond to the stated requirements. This should result in clear and focused technical specifications and requirements (balancing objectives with budget), an appropriate choice of procurement methods (taking into account of both costs and risks) likely to attract the best response from the market, and a contract type best suited to achieving the desired results.

8. Evaluation criteria must be designed to enable the borrower to achieve value for money taking into account the cost- and noncost-based criteria needed to achieve the procurement needs and objectives. This will include consideration of the quality of the goods and services, responsiveness to socioeconomic or environmental objectives, fitness for purpose, the bidders' record of achieving the desired results based on experience and performance history, and methods of assessing costs such as life cycle costing (including initial price together with, as appropriate, costs of maintenance, operation, licensing, additional features, consumables, disposal, etc.).

9. Where quality standards of the technical requirements can be established and measured easily by reference to technical specifications 
or well-established industry standards, value for money will be achieved by applying evaluation based on the lowest evaluated cost for goods, works, and services substantially meeting those requirements.

This will be the case for standard off-the-shelf goods and equipment and standard construction and other nonconsulting services.

10. In situations where quality needs to be measured by comparing providers based on an assessment of qualification, experience, and performance (such as consultancy services or where complex solutions consisting of a combination of goods, works, and services are required), value for money is likely to be achieved by applying evaluation methods which allow for an assessment of the balance between cost and quality according to the needs of the borrower as well as intended project development objectives.

11. The procurement plan should take into account the potential risks, balancing the need to ensure competition with efficiency in use of public resources, transparency and accountability, and risk management. 


\section{APPENDIX 2}

\section{Procurement Planning}

1. The procurement plan is based on a full assessment of the needs and objectives of the borrower and describes the project activities to support them.

2. The scope and details of the procurement plan take into account, and are proportional to, the relevant market, scale, risk, value, and country circumstances, including, when applicable, situations of urgent need of assistance or capacity constraints, and the specific economic, environmental, and social objectives of the project.

3. The procurement plan sets forth

(a) the particular contracts for the goods, works, and/or services required in carrying out the project;

(b) the proposed methods for procurement of such contracts that are permitted;

(c) the type of bidding documents to be used; and

(d) the related $A D B$ review procedures and proposed contract supervision arrangements.

4. In preparing the procurement plan, the following are typically considered:

(a) Strategic aims:

(i) development objectives for the project,

(ii) required outcomes,

(iii) performance measures,

(iv) implementing agency capacity and resources, and

(v) project risks.

(b) Operational context:

(i) governance aspects (fragile or conflict-affected situation, state involvement in the economy, legislative processes and legal framework), 
(ii) economic aspects (small economy, inflation, domestic preference, and exchange rate volatility),

(iii) sustainability aspects (disaster or emergency situation, sustainability requirements), and

(iv) technological aspects (availability of informational technology, information transfer, and security; internet access and restrictions; cell phone access and coverage).

(c) Market research: To develop a thorough understanding of the relevant sectors and potential bidders and/or consultants in the market. How the market works and how this may impact the procurement methods used to procure. The market research assesses issues that affect the risks and results of the project.

(d) Risk management: Comprising all major risks related to the operating environment, market conditions, implementing agency capability, and provider capability. Procurement risks and opportunities identified to be managed through the procurement process, including procurement design, technical specifications, contractual terms and conditions, evaluation criteria, and contract management.

(e) Procurement arrangements: Comprising procurement methods, qualification and evaluation criteria, and contracting strategy (contract packaging, types of contracts, key contractual provisions, and key delivery and payment milestones) including the justification for each decision; and outline of the key specifications and quality requirements.

5. When deciding which procurement method is most suitable, the following may be considered:

(a) identification of the specific project needs;

(b) assessment of the adequacy, behavior, and capabilities of the market to respond to the procurement;

(c) assessment of the implementing agency's resources and previous experience in procuring these types of activities;

(d) justification of procurement decisions including an analysis of the strengths and weaknesses of the procurement methods and 
selection methods for the delivery of the project development objectives; and

(e) justification of the proposed qualification and evaluation methods in terms of market analysis, risk and country context, and the project's particular circumstances.

6. The borrower prepares and furnishes the draft procurement plan to ADB as part of project preparation, to be agreed by ADB before loan negotiations. The borrower updates the procurement plan annually or as needed throughout the duration of the project. Any changes or modifications to a procurement plan by a borrower are subject to ADB concurrence.

7. To provide early information to potential bidders, ADB publicly discloses all initial procurement plans (and any subsequent updates) indicating the general scope and value of procurement for the succeeding year. 


\section{APPENDIX 3}

\section{Open Competitive Bidding Procedure}

1. Subject to any differences set out in Appendix 4 in respect of consulting services, the provisions of this appendix apply to procurement of goods, works, and services.

\section{Type and Size of Contracts}

2. The bidding documents shall clearly state the type of contract to be entered into and contain the proposed contract provisions. Contract types and arrangements shall be selected based on their fitness for purpose, taking into account the subject matter of the procurement and risk, to achieve value for money. The most common types of contracts provide for payments on the basis of a lump sum, time-based, or unit prices, or combinations thereof.

3. For a project requiring similar but separate items of nonconsulting services, equipment, or works, bids may be invited under alternative contract options that would attract the interest of both small and large firms. In such cases, firms may be allowed, at their option, to bid for individual contracts (lots or slices) or for a group of similar contracts (package). All bids and combinations of bids shall be received by the same deadline and evaluated simultaneously to determine the bid or combination of bids offering the optimum value for money.

4. In certain cases, ADB may accept or require a turnkey contract under which the design and engineering, the supply and installation of equipment, and the construction of a complete facility or works are provided under a single responsibility contract. Alternatively, the borrower may remain responsible for the design and engineering and invite bids for a contract for the supply and installation of all goods, works, and services required for the project component. Design and 
build, management contracts, ${ }^{1}$ and comparable legal agreements are also acceptable where appropriate.

\section{Two-Stage Bidding}

5. In the case of turnkey contracts or contracts for large complex facilities, works or nonconsulting services of a special nature, or involving complex information and communication technology, it may be undesirable or impractical to prepare complete technical specifications in advance. In such a case, a two-stage bidding procedure may be used, under which unpriced technical proposals are generally invited first.

These are prepared on the basis of a conceptual design or performance specification and are subject to technical as well as commercial clarifications and adjustments.

6. The first-stage technical proposal clarification is to be followed by issuance of amended bidding documents ${ }^{2}$ and/or memorandum of changes required to first-stage bids as may be required, and the submission of final technical proposals and priced bids in the second stage.

7. First-stage technical proposals may, in some cases, be accompanied by a sealed financial proposal. Following finalization of the technical specifications, the revised technical proposals would be accompanied by a revised financial proposal.

\section{Two-Envelope Bidding}

8. Under a two-envelope procedure, typically used in the context of a single-stage bidding process, bids are submitted simultaneously in two separate envelopes-one containing the technical proposal and another containing the financial proposal.

\footnotetext{
In construction, a management contractor usually does not perform the work directly but contracts out and manages the work of other contractors, taking on the full responsibility and risk for price, quality, and timely performance. Conversely, a construction manager is a consultant for, or agent of, the borrower but does not take on such risks.

2 In revising the bidding documents in the second stage, the borrower should respect the confidentiality of the bidders' technical proposals used in the first stage, consistent with requirements of transparency and intellectual property rights.
} 
9. The financial proposals of bidders whose technical proposals are not responsive shall be returned unopened.

\section{Notification and Advertising}

10. Timely notification of bidding opportunities is essential in competitive bidding, providing bidders with sufficient time to prepare and submit their bids. Advertising may be carried out internationally or nationally, as follows:

(a) Where international advertising is suitable or required, invitations to prequalify or to bid will be published on the $A D B$ website ${ }^{3}$ as well as

- $\quad$ on a freely and publicly accessible website in English; and

- a newspaper of national circulation (at least in one English language newspaper, if available) or website in the borrower's country.

A copy of the invitation for bids shall be submitted to ADB for noobjection and for publication on the ADB website in accordance with the provisions of the financing agreement.

(b) Advertising of invitations to prequalify or to bid, as the case may be, can be carried out solely in the national press or official gazette or a free and publicly accessible website when by their nature or scope procurements is unlikely to attract foreign competition. This may be appropriate where foreign bidders are not expected to be interested because

(i) the contract value is small;

(ii) works are scattered geographically or spread over time;

(iii) works are labor intensive; or

(iv) the goods, works, or services are available locally at prices below the international market.

11. The notice shall contain information concerning the borrower (or prospective borrower), amount and purpose of the loan, scope of procurement under open competitive bidding, and the name, telephone number, e-mail address, and address of the borrower's 
agency responsible for procurement and/or website where the bidding documents can be obtained. The prequalification or bidding documents, as the case may be, shall not be released to the public earlier than the date of publication of the relevant advertisement.

\section{Prequalification of Bidders}

12. Prequalification ${ }^{4}$ is a mechanism that ensures that only those who have adequate capabilities and resources submit bids or proposals, as the case may be.

13. It may be used for all procurement, although the terminology may change depending on the nature of the procurement in question. In the case of goods, works, and nonconsulting services, it is referred to as prequalification. In the case of consulting services, it is generally referred to as short-listing, and applications to be short-listed are referred to as expressions of interest. However, the process and significance are identical.

14. Prequalification is generally recommended for

(a) consulting services,

(b) large or complex works, or

(c) any other circumstances in which the high costs of preparing detailed bids could discourage competition. ${ }^{5}$

15. Prequalification is based upon the capability and resources of prospective bidders to perform the particular contract satisfactorily, taking into account, as appropriate, their

(a) experience and past performance on similar contracts,

(b) capabilities with respect to the subject matter of the contract, ${ }^{6}$ and

(c) financial position.

Prequalification includes, in the context of consulting services, the process of short-listing firms.

Such as custom-designed equipment, industrial plant, specialized services, some complex

information and communication technology contracts, and contracts to be let under turnkey, design and build, or management contracting.

6 This may include (i) construction or manufacturing facilities in the case of goods and works;

(ii) similar regional or country exposure; and (iii) related sector experience and past performance in the case of consulting services. 
16. The prequalification requirements shall be made available to potential bidders and consultants in an objective and transparent manner and published as appropriate.

17. Potential applicants shall be allowed sufficient time for the submission of prequalification applications (or expressions of interest in the case of consulting services) so that they have adequate time to review and prepare their applications. To encourage competition, all those found capable of performing the work satisfactorily in accordance with the approved prequalification criteria shall be invited to submit bids.

18. ADB does not recommend long gaps between completion of prequalification and commencement of the bidding process, and therefore encourages the bidding documents to be made available to the prequalified prospective bidders as soon as prequalification is completed.

19. The borrower may decide to limit the number of firms to be prequalified based on criteria clearly stated in the prequalification documents, as long as this does not limit fair competition.

20. For prequalification for groups of contracts to be awarded over a period of time, a limit for the number or total value of awards to any one bidder may be made on the basis of the adequacy of the bidder's technical and financial resources and to prevent failure of bidders to satisfactorily perform the contract. The list of prequalified firms in such instances shall be updated periodically to keep the list current. $A D B$ also recommends verification of the information provided in the submission for prequalification at the time of award of contract. Award of contract may be denied to a bidder who is judged to no longer have the capability or resources to successfully perform the contract.

\section{Joint Ventures}

21. Any firm may bid independently or in joint venture confirming joint and several liability, either with domestic firms and/or with foreign firms. ${ }^{7}$ To promote open competition, ADB does not ordinarily accept conditions of bidding requiring mandatory joint ventures or other forms of mandatory association between firms.

In particular circumstances, a firm may bid independently yet include either subcontractors (for goods and works) or associated subconsultants (for consulting services) to carry out particular tasks. 


\section{Bidding Documents}

22. It is essential that the bidding documents provide all the information necessary for bidders to prepare responsive bids, although the detail and complexity of these documents will vary depending upon the kind of goods, works, or services to be procured and the size of the contract.

23. The term standard bidding document (SBD) is used to refer to standardized documents for all procurement methods and used to promote consistency and legal certainty. Where mandated in the procurement plan, borrowers shall use the appropriate SBDs where such SBDs have been issued by ADB. Where no relevant SBD has been issued by $A D B$, the borrower may use other internationally or nationally recognized standard conditions of contract and contract forms provided they are consistent with these Regulations.

24. SBDs shall reflect the nature of procurement. For example, in the case of consultancy services, an invitation to bid shall be referred to as a request for proposals.

25. ADB recommends borrowers use an electronic system to distribute bidding documents.

\section{Validity of Bids and Bid Security}

26. Bidders are required to submit bids valid for a period specified in the bidding documents sufficient to enable the borrower to complete the comparison and evaluation of bids, review the recommendation of award with ADB (if prior review is required), and obtain all the necessary approvals and/or no-objections so that the contract can be awarded within that period.

27. In the case of contracts for goods, works, and services other than consulting services, borrowers have the option of requiring a bid security. When used, the amount of the bid security will be in the form and amount specified in the bidding documents. The bid security will remain valid for a period specified in the bidding documents. Bid security shall be released to unsuccessful bidders once the contract has been signed with the winning bidder.

28. In place of a bid security, the borrower may require bidders to sign a bid-securing declaration accepting that if they withdraw or modify their 
bids during the period of validity, or they are awarded the contract and they fail to either sign the contract or submit a performance security before the deadline defined in the bidding documents, the bidder will be suspended for a period of time from being eligible for bidding in any contract with the borrower.

\section{Language}

29. Unless otherwise agreed by ADB, bidding and other relevant documents, including advertisements, are to be prepared in English.

\section{Clarity of Bidding Documents}

30. Bidding documents must be clearly worded to permit and encourage open competition and shall set forth unambiguously and precisely the borrower's requirements.

31. Where consideration of factors, in addition to price, are to be taken into account in evaluating bids, such factors and an explanation of how they will be quantified or otherwise evaluated must appear in the bidding documents to inform bidders of the method of evaluation.

32. If bids based on alternative designs, materials, completion schedules, payment terms, etc., are permitted, conditions for their acceptability and the method of their evaluation shall be expressly stated.

33. To ensure fair treatment, all prospective bidders must be provided the same information in the same and timely manner and must be provided reasonable access to project sites.

34. For works or complex supply or services contracts, a pre-bid conference may be arranged for potential bidders to meet with the borrower's representatives to seek clarifications (in person or online). Minutes of the conference shall be provided to all prospective bidders and a copy supplied to ADB.

35. To ensure equal treatment, any additional information, clarification, correction of errors, or modifications of bidding documents will be sent to each recipient of the original bidding documents in sufficient time before the deadline for receipt of bids to enable bidders to take appropriate actions. If necessary, the deadline can be extended. 


\section{Specifying Quality}

36. The bidding documents must adequately set out the borrower's requirements in terms of the work to be carried out, the location of the work, the goods to be supplied, the place of delivery or installation, the services to be delivered, the schedule for delivery or completion, minimum performance requirements, and the warranty and maintenance requirements, as well as any other pertinent terms and conditions.

37. The technical and quality requirements of the borrower will be articulated in the bidding documents based on a clear and comprehensive statement of the borrower's needs. The requirements will detail the nature and scope of the goods and/or services that will be required to satisfy those needs and set out any quality or other standards to be met.

38. The borrower's requirements will ordinarily be formulated in terms of performance or functional requirements or by reference to technical specifications and industry standards.

39. Where appropriate, the bidding documents will define any tests, standards, and methods that will be employed to judge the conformity of equipment as delivered, or works or services as performed, with specifications.

40. In the case of consulting services, requirements will be established in the terms of reference which define clearly the objectives, goals, and scope of the assignment and provide background information.

41. To promote the broadest possible competition while assuring the critical performance or other requirements for the goods and/or works under procurement, standards and technical specifications quoted in bidding documents should, as far as possible, be specified by way of internationally accepted standards such as those issued by the International Standards Organization. Where such international standards are unavailable, national standards may be specified. In all cases, equivalent standards are acceptable.

\section{Use of Brand Names}

42. To avoid discrimination, references to brand names, catalog numbers, or similar classifications are not permitted. However, if it is necessary to 
quote a brand name or catalog number of a particular manufacturer to clarify an otherwise incomplete specification, the words "or equivalent" need to be added after such reference.

43. The specification must permit the acceptance of offers for goods that have similar characteristics and provide performance substantially equivalent to those specified.

\section{Pricing for Goods and Works}

44. Bids for goods shall be invited on the basis of cost, insurance, and freight (CIF), or cost and insurance to place of destination (CIP) for all goods offered from abroad, and ex-works (EXW) ${ }^{8}$ for locally available or manufactured or assembled goods, including those previously imported. Where inland transportation, installation, commissioning, or other similar services are required to be performed by the bidder, as in the case of supply and installation contracts, the bidder shall be required to provide a separate quotation for these services.

45. In the case of turnkey contracts, the bidder shall be required to quote the price of the installed plant at site, including all costs for supply of equipment, marine and local transportation and insurance, installation and commissioning, as well as associated works and all other services included in the scope of contract such as design, maintenance, and operation. Unless otherwise specified in the bidding documents, the turnkey price shall include all duties, taxes, and other levies. ${ }^{9}$

46. Bidders for civil works contracts shall generally be required to quote unit prices or lump-sum prices for the performance of the works, and such prices shall include all duties, taxes, and other levies.

8 Refer to applicable version of Incoterms for further definitions published by the International Chamber of Commerce, 38 Cours Albert 1er, 75008 Paris, France.

9 Costs of taxes and duties related to project expenditure are eligible for ADB financing provided the amounts to be financed are reasonable, provided the relevant country tax regime has been assessed as having sufficient transparency, competitive neutrality, and sustainability. ADB. 2005. Cost Saving and Eligibility of Expenditures for Asian Development Bank Financing: A New Approach. Manila. https:// www.adb.org/documents/cost-sharing-and-eligibility-expenditures-asian-development-bankfinancing-new-approach 


\section{Price Adjustment}

47. The bidding documents shall clearly indicate whether price adjustments are allowed in the event of inflation or of changes that occur in major cost components of the contract, such as labor, equipment, and materials, over which the contractor has no control. The amount of price adjustment shall be based on changes in the cost of the major components of the contract. If used, the bidding documents shall provide the method of adjustment formula or formulas to be used. The comparison of bid prices shall be carried out on the basis of base price only.

\section{Transportation and Insurance}

48. Bidding documents shall permit suppliers and contractors to arrange transportation and insurance from any eligible source. Bidding documents shall state the types and terms of insurance to be provided by the bidder.

\section{Professional Liability}

49. Service providers are expected to carry out assignments with due diligence and in accordance with prevailing standards of the profession. If the parties seek to limit this liability by way of contract, they should ensure that

(a) there must be no such limitation in case of the service provider's negligence or misconduct,

(b) the service provider's liability to the borrower may in no case be limited to less than a multiplier of the total value of the contract to be indicated in the bidding document and in the special conditions of the contract (the amount of such limitation will depend on each specific case), and

(c) any such limitation may deal only with the service provider's liability toward the client and not with the service provider's liability toward third parties. 


\section{Currency Provisions}

50. Bidding documents shall state the currency or currencies in which bidders are to state their prices, the procedure for conversion of prices expressed in different currencies into a single currency for the purpose of comparing bids, and the currencies in which the contract price will be paid.

\section{Alternative Bids}

51. The bidding documents shall clearly indicate when bidders are allowed to submit alternative bids, how alternative bids should be submitted, how bid prices should be offered, and the basis on which alternative bids shall be evaluated.

\section{Conditions of Contract}

52. The contract documents shall clearly define the scope of work to be performed; the goods to be supplied; the services to be delivered; the rights and obligations of the borrower and of the supplier, contractor, or service provider; and the functions and authority of the engineer, architect, or construction manager, if one is employed by the borrower, in the supervision and administration of the contract.

53. In addition to the general conditions of contract, any special conditions particular to the specific goods, works, or services to be procured and the location of the project shall be included. The conditions of contract shall provide a balanced allocation of risks and liabilities.

\section{Contract Management}

54. The aim of contract management ${ }^{10}$ is to ensure that all parties meet their obligations. The borrower (through the relevant executing agency) must actively manage contracts throughout their life to ensure that contractor performance is satisfactory, appropriate stakeholders are informed, and all contract requirements are met.

10 Appendix 8, para. 3. 


\section{Performance Security}

55. In the case of contracts for goods, works, and nonconsulting services, the bidding documents shall set out the requirements in respect of performance security.

\section{Liquidated Damages and Bonus Clauses}

56. Provisions for liquidated damages or similar provisions in an appropriate amount shall be included in the conditions of contract when delays in the delivery of goods, completion of works or services other than consulting services, or failure of the goods or works to meet performance requirements would result in extra cost or loss of revenue or other benefits to the borrower.

57. Provision may also be made for a bonus to be paid to suppliers, contractors, or service providers for completion of works or services or delivery of goods ahead of the times specified in the contract when such earlier completion or delivery would be of benefit to the borrower.

\section{Force Majeure}

58. The conditions of contract shall stipulate that failure on the part of the parties to perform their obligations under the contract will not be considered a default if such failure is the result of an event of force majeure as defined in the conditions of contract.

\section{Applicable Law and Settlement of Disputes}

59. The conditions of contract shall include provisions dealing with the applicable law and the forum for the settlement of disputes. ADB's preference is that borrowers use international commercial arbitration in contracts for the procurement of goods, works, and services. ADB shall not be named arbitrator or be asked to name an arbitrator. In case of works contracts, supply and installation contracts, and turnkey contracts, the dispute settlement provision may also include mechanisms such as dispute review boards or adjudicators, which are designed to permit a speedier dispute settlement. 


\section{Time for Preparation of Bids}

60. The time allowed for the preparation and submission of bids shall be determined with due consideration of the particular circumstances of the project and the magnitude and complexity of the contract.

61. Minimum time periods may be reduced where notifications are sent and/or submissions accepted electronically. Where large works or services or complex items of equipment are involved, a longer period may be necessary to enable prospective bidders to conduct investigations before submitting their bids. In such cases, the borrower is encouraged to convene pre-bid conferences and arrange site visits. The deadline and place for receipt of bids shall be specified in the invitation for bids and the bidding documents.

\section{Bid Opening Procedures}

62. Bid opening procedures depend on whether the procedure is based on the submission of one or two envelopes in one or two stages.

63. In the case of a single-stage one-envelope procedure used for the majority of contracts for goods, works, and services other than consulting services, the time for the bid opening shall be the same as for the deadline for receipt of bids or promptly thereafter, and shall be identified, together with the place for bid opening, in the bidding document.

64. The borrower shall open all bids at the stipulated time and place. Bids shall be opened in public; bidders or their representatives shall be allowed to be present in person (or online, when electronic bidding is used). The name of the bidder and total amount of each bid, and of any alternative bids if they have been requested or permitted, shall be read aloud (and posted online when electronic bidding is used) and recorded when opened, and a copy of this record shall be promptly sent to ADB and to all bidders who submitted bids in time.

65. Bids received after the time stipulated, as well as those not opened and read out at bid opening, shall not be considered. When electronic bid submission is used, an online bid opening procedure acceptable to ADB may be employed. 
66. In the case of a single-stage two-envelope system, which is used predominantly for consulting services but also when justified for goods, works, and nonconsulting services contracts, bids with separate envelopes for technical and financial proposals are submitted simultaneously.

67. The technical proposal is opened first to determine responsiveness to the bidding documents. Only the financial proposals of bidders with responsive technical proposals are opened for evaluation and comparison. The financial proposals of bidders whose technical proposals are not responsive shall be returned promptly unopened.

68. In the case of consulting services, review of the technical proposal shall be based on the evaluation criteria defined in the bidding documents. After the technical quality is evaluated,

(a) firms whose technical proposals did not meet the minimum specified qualifying score or were considered nonresponsive to the invitation requirements will be advised and their financial proposals will be returned unopened; and

(b) firms that have secured the minimum qualifying technical score will be advised of the location, date, and time for opening of financial proposals; the name of the firms, the technical quality scores, and the proposed prices shall be announced, and recorded when the financial proposals are opened.

\section{Clarifications or Alterations of Bids}

69. Bidders are not permitted to alter their bids after the deadline for bid receipt. The borrower may ask bidders for any clarification needed to evaluate their bids but shall not ask or permit bidders to change the substance or price of their bids after the bid opening or to provide material documents required by the bidding documents.

70. Requests for clarification and the bidders' responses shall be made in writing or through a secure electronic system.

\section{Confidentiality}

71. After the public opening of bids, information relating to the examination, clarification, and evaluation of bids and recommendations 
concerning awards shall not be disclosed to bidders or other persons not officially concerned with this process until the publication of contract award.

\section{Examination of Bids}

72. The borrower shall ascertain if the bids

(a) meet the eligibility requirements;

(b) have been properly signed;

(c) are accompanied by the required securities, if any, or required bidsecuring declaration;

(d) are substantially responsive to the bidding documents; and

(e) are otherwise generally in order.

73. If a bid is not substantially responsive, i.e., it contains material deviations from or reservations to the terms, conditions, and specifications in the bidding documents, it shall not be considered further. The bidder shall not be permitted to correct or withdraw material deviations or reservations once bids have been opened.

\section{Evaluation and Comparison of Bids}

74. The aim of evaluation is to identify the substantially responsive bid offering the optimum value for money. Value for money is to be determined on the basis of a combination of factors depending on the nature and scope of the procurement in question. This is covered in Appendix 1.

\section{Evaluation Report}

75. The borrower shall prepare a detailed report on the evaluation and comparison of bids setting forth the specific reasons on which the recommendation is based for the award of the contract. 


\section{Abnormally Low Bids}

76. Any procedure under which bids above or below a predetermined assessment of bid values are automatically disqualified is not acceptable. However, an abnormally low bid may be excluded or made subject to certain conditions where the bid price appears so unreasonably low that it raises concerns with the borrower in respect of the bidder's ability to perform the contract successfully.

77. When such a bid is identified, the borrower shall seek written explanations of the proposed price or costs from the bidder, including a detailed analysis of its bid prices by reference to the scope, proposed methodology, schedule, and allocation of risks and responsibilities.

78. This may also include information regarding the economy of the manufacturing process, the services provided, or the construction method; the technical solutions chosen or any exceptionally favorable conditions available to the bidder for the supply of the products or services or for the execution of the work; or the originality of the work, supplies, or services proposed.

79. After examining the explanation given and the detailed price analyses presented by the bidder, the borrower may

(a) accept the bid,

(b) require that the amount of the performance security be increased at the expense of the bidder to a level sufficient to protect the borrower against financial loss in the event of default of the successful bidder under the contract, or

(c) reject the bid where the evidence supplied does not satisfactorily account for the low level of price or costs proposed.

\section{Domestic Preferences}

80. ADB may accept the application of provisions that promote or encourage the development of domestic industry through domestic preference schemes provided that ADB is satisfied that such provisions satisfy the Core Procurement Principles.

81. Where domestic preference margins are permitted by other development partners in ADB's developing member countries, ADB may permit the application of the same. 
82. The agreed approaches are reflected in the procurement plan.

\section{Extension of Validity of Bids}

83. Borrowers shall complete evaluation of bids and award of contract within the initial period of bid validity so that extensions are not necessary. An extension of bid validity, if adequately justified, shall be requested in writing from all bidders before the expiration date.

84. The extension shall be for the minimum period required to complete the evaluation, obtain the necessary approvals and/or no-objections, and award the contract. Whenever an extension of bid validity period is requested, bidders shall not be requested or be permitted to change the price or other conditions of their bid. Bidders shall have the right to refuse to grant such an extension.

85. If the bidding documents require a bid security, bidders may exercise their right to refuse to grant such an extension without forfeiting their bid security. Those bidders willing to extend the validity of their bid shall be required to provide a suitable unconditional extension of bid security.

\section{Post Qualification of Bidders}

86. If bidders have not been prequalified, the borrower shall determine whether the proposed successful bidder has the capability and resources to effectively carry out the goods or works contract as offered in the bid. The criteria to be satisfied shall be consistent with para. 1.17 and set out in the bidding documents, and if the bidder does not fulfill the criteria, the bid shall be rejected. In such an event, the borrower shall make a similar determination for the next bidder.

\section{Intention for Award of Contract}

87. ADB may permit application of national standstill provisions or those of another development partner. Where standstill provisions apply, 
the borrower shall within the standstill period ${ }^{11}$ notify in writing each bidder that submitted a bid of its intention to award a contract to the successful bidder at the end of the standstill period, and shall include with that notification

(a) the name of each bidder who submitted a bid;

(b) the bid prices as read out at bid opening;

(c) the name and evaluated prices or technical and financial scores of each bid that was evaluated;

(d) the name of bidders whose bids were rejected and the reasons for their rejection;

(e) the name of the winning bidder, and the price it offered or score it achieved, as well as the duration and summary scope of the contract awarded; and

(f) a statement of the reason(s) the bid of the unsuccessful bidder to whom the notification addressed was unsuccessful, unless the price information under (e) of this paragraph already reveals the reason.

88. In no case shall any bidder's cost breakdown, trade secrets, manufacturing processes and techniques, or other confidential business or financial information be disclosed to any other bidder.

89. Subject to any standstill provisions that apply, the borrower shall award the contract, within the period of bid validity, to the bidder who meets the appropriate standards of capability and resources and whose bid has been determined to be substantially responsive to the bidding documents and to offer either

(a) the lowest evaluated cost; or

(b) the best combination of quality and price, as appropriate and according to contract type (e.g., consulting services), based on the criteria identified in the bidding documents.

90. A bidder shall not be required, as a condition of award, to undertake responsibilities for work not stipulated in the bidding documents or otherwise to modify the bid as originally submitted.

Standstill period is defined in bidding documents to specify the duration subsequent to notification of intention for award of contract (before making the actual contract award) within which any unsuccessful bidder can challenge the proposed award. 


\section{Publication of the Award of Contract}

91. Within 2 weeks of the award of contract or expiry of the standstill period, where such period applies, or, if a complaint has been filed within the standstill period, upon receipt of ADB's confirmation of satisfactory resolution of the complaint, the borrower shall transmit the notice of award to the successful bidder and publish in an English language newspaper or widely known and freely accessible website the results identifying the bid and lot or package numbers as applicable, and the information contained in para. 87 of this appendix.

\section{Rejection of All Bids}

92. Bidding documents usually provide that borrowers may reject all bids. Rejection of all bids is justified when there is lack of effective competition, bids are not substantially responsive, or when bid prices are substantially higher than the existing budget. Lack of competition shall not be determined solely on the basis of the number of bidders.

93. Even when only one bid is submitted, the bidding process may be considered valid if the bid was satisfactorily advertised and prices are reasonable in comparison to market values.

94. Borrowers may reject all bids. If all bids are rejected, the borrower shall review the causes justifying the rejection and consider making revisions to the conditions of the contract, design and specifications, scope of the contract, or a combination of these before inviting new bids.

95. If the rejection of all bids is due to lack of competition, wider advertising shall be considered. If the rejection is due to most or all of the bids being nonresponsive, new bids may be invited from the initially prequalified firms, or, with the agreement of $A D B$, from only those that submitted bids in the first instance, provided the borrower has carefully considered and addressed the reasons for the earlier lack of bid responsiveness and, as appropriate, modified or amended the bidding documents.

96. When all bids have been rejected, a rebidding may be called and the borrower shall request new bids from among others all who were supplied with bidding documents in the first instance.

97. However, if there has been a sufficient number of bids in the initial bidding, the borrower may consider inviting bids only from those who 
have previously submitted bids. Where all bid prices substantially exceed the cost estimates, the borrower may, after reviewing the sufficiency of the original budget, instead of calling for new bids, and after consultation with $\mathrm{ADB}$, do either of the following:

(a) In the case of contracts for works, goods, and services other than consulting services, negotiate with the lowest evaluated bidder for a reduction of the bid price. If no satisfactory contract can be concluded and a rebidding is called, modification of the scope of the contract shall be considered.

(b) In the case of consulting contracts, negotiate a contract with the first-ranked firm based on the combined technical and financial scores. Negotiations will include discussions of the terms of reference including scope, methodology, personnel schedule, the borrower's counterpart facilities, and the quantities of cost items in the firm's financial proposal. However, these discussions will not substantially alter the terms of reference attached to the bidding document. ${ }^{12}$

98. For contracts subject to $\mathrm{ADB}$ prior review, ADB's prior no-objection shall be obtained before rejecting all bids, soliciting new bids, substantially changing the original budget and/or estimate, or entering into negotiations with the lowest evaluated bidder.

\section{Debriefing}

99. In the notification of contract award, the borrower shall specify that any bidder who wishes to ascertain the grounds on which its bid was not selected should request an explanation from the borrower.

The borrower shall promptly, in writing and/or in a debriefing meeting, and in any event before the end of the standstill period if it applies, provide an explanation of why such bid was not selected. If the bidder is not satisfied with the explanation provided by the borrower or if the borrower fails to provide such debriefing, the bidder may write directly to ADB. The requesting bidder shall bear all the costs of attending a debriefing.

The selected firm may not be allowed to substitute experts unless both parties agree that undue delay in the selection process makes such substitution unavoidable or that such changes are critical to meet the objectives of the assignment. Proposed unit rates for remuneration shall not be altered and other expenses shall not be negotiated where the unit rate cost has been a factor in the selection process. 


\section{APPENDIX 4 \\ Consulting Services Selection Using Open Competitive Bidding}

\section{Short-Listing}

1. In the case of consulting services, prequalification is done using a shortlisting process.

2. Borrowers will advertise a request for expressions of interest (REOI) which sets out the criteria to be applied to select the short list of bidders for consultancy contracts. The borrower may decide to limit the number of bidders appearing on the short list, and the objective criteria for doing so shall be set out in the REOI.

3. The short-listed firms shall be invited to bid by way of a request for proposals (RFP).

4. RFPs shall be prepared containing the relevant documents and forms.

\section{Selection Methods}

5. In the case of contracts for consulting services, value for money is normally based on the best combination of quality and price appropriate to the service in question. This is achieved through competition among prequalified (short-listed) firms in which the selection is based on the quality of the proposal and, where appropriate, on the cost of the services to be provided.

6. The quality- and cost-based selection (QCBS) method is appropriate when
(a) the scope of work can be precisely defined;
(b) the terms of reference (TOR) are well-specified and clear; and
(c) the borrower (or, as applicable, Asian Development Bank [ADB]) 
and the consultants can estimate with reasonable precision the personnel time as well as the other inputs required of the consultants. The weightage for the cost shall be chosen, taking into account the complexity and impact of the assignment and the relative importance of quality.

7. In particular cases, consulting services are evaluated under a qualitybased selection (QBS) method where only the quality of the technical proposals is evaluated. QBS is appropriate when

(a) assignments are complex or highly specialized, making it difficult to define precise TOR and the required input from the consultants;

(b) the downstream impact of the assignment is so large that the quality of the services is of overriding importance for the outcome of the project; and

(c) assignments can be carried out in substantially different ways such that financial proposals may be difficult to compare.

8. In some cases, quality is also paramount for small assignments where selection based on consultants' qualifications (CQS) may be used, if

(a) highly specialized expertise is required for the assignment and recruitment of "boutique" consulting firms that provide depth of expertise in specific areas is contemplated;

(b) recruitment time is critical and the assignment is, typically, short term;

(c) few consultants are qualified; and

(d) the preparation and evaluation of competitive proposals is not justified.

9. Fixed-budget selection (FBS) is appropriate when

(a) the TOR are precisely defined,

(b) the time and personnel inputs can be accurately assessed, and

(c) the budget is fixed and cannot be exceeded.

10. Least-cost selection (LCS) is the appropriate method for selecting consultants for small assignments of a standard or routine nature ${ }^{1}$ where well-established practices and standards exist. 


\section{Pricing for Consulting Services}

11. For time-based consulting contracts, ${ }^{2}$ payments are linked to inputs and bidders will be required to quote prices based on the identified inputs, such as monthly rates for personnel named in the contract, and on reimbursable expenses using actual expenses and/or an agreed unit rate. In other cases, pricing may be agreed on alternative bases such as lump-sum fees, ${ }^{3}$ agreed remuneration rates for experts typically payable on the basis of the time inputs actually provided in the case of indefinite delivery (price agreement) contracts, ${ }^{4}$ percentage payments based on performance ${ }^{5}$ triggered on the achievement of selected milestones, or a success fee (normally expressed as a percentage of the sale price of the assets) for retainer or contingency (success) fee contracts. ${ }^{6}$

\section{Evaluation Criteria and Methodology for Consulting Services}

12. Quality in respect of the provision of consultancy services is not readily assessed on the basis of standard technical specifications, given the importance of consultant qualifications, experience, and performance. At the same time, the nature of the services to be provided and the

2 These may be used when it is difficult to define the scope, output, and the length of the services, either because the services are related to and await completion of activities by others for which the completion period may vary, or because the input of the consultants is difficult to assess.

This type of contract will be used for complex studies, supervision of construction, advisory services, and most training assignments.

3 Lump-sum contracts are used for assignments in which the content, duration of services, and the required output of the consultants are clearly defined. This includes simple planning and feasibility studies, environmental studies, detailed design of standard or common structures, service delivery assignments, and preparation of data processing systems.

4 This contract is used when borrowers need to have on-call specialized services to provide advice on a particular activity, the extent and timing of which cannot be defined in advance and is commonly used to retain advisers for implementation of complex projects, expert adjudicators for dispute resolution panels, institutional reforms, procurement advice, and technical troubleshooting, normally for a period of a year or more.

5 A performance-based contract is used to enhance the delivery of consulting services outputs, thereby improving value for money.

6 These contracts are widely used when consultants (banks or financial firms) are preparing companies for sale or merger, notably in privatization operations. 
degree of intellectual input required ${ }^{7}$ will dictate the level of quality required versus the cost.

13. The evaluation methodology for various methods used for consulting services selection is described in Appendix 5.

Some consulting services require qualified professionals to carry out routine tasks according to standard procedures (e.g., bookkeeping or notarial services) which require no additional creative input. Other services are not routine and require additional intellectual creativity (e.g., forensic accounting or litigation advice) where the experience and performance record of the professional is paramount. 


\section{APPENDIX 5}

\section{Evaluation Criteria and Methodology}

1. Evaluation criteria shall be designed to enable the borrower to achieve value for money in procurement financed by the Asian Development Bank (ADB) and shall be informed by the procurement plan.

\section{Key Requirements}

2. The evaluation criteria shall be appropriate to the nature and complexity of the procurement and

(a) be proportionate and appropriate to the type, nature, market conditions, complexity, risk, value, and objective of what is being procured;

(b) to the extent practicable, be quantifiable (such as convertible to monetary terms);

(c) be included (to the exclusion of all other criteria) in the bidding or request for proposals documents together with a full explanation of the specific manner in which they are to be applied;

(d) be changed only through amendments; and

(e) be applied consistently to all bids or proposals submitted.

3. In particular, the evaluation criteria shall reflect the nature of the procurement and the need to balance the cost and quality elements appropriately.

(a) Where quality standards of the technical requirements can be established and measured easily by reference to technical specifications or well-established industry standards, value for money will be achieved by applying evaluation based on lowest evaluated cost for goods, works, and services substantially meeting those requirements. This will be the case for standard off-theshelf goods and equipment and standard construction and other nonconsulting services. 
(b) Where quality needs to be measured by comparison between providers based on an assessment of qualification, experience, and performance, such as in the case of consultancy services, or where complex solutions are required consisting of a combination of goods, works, and services, value for money is more likely to be achieved by applying evaluation methods which allow for an assessment of the balance between cost and quality according to the needs of the borrower as well as intended project development objectives.

\section{Evaluating Goods, Works, and Nonconsulting Services}

4. In the case of contracts for goods, works, and nonconsulting services, value for money is generally determined on the basis of the lowest substantially responsive evaluated cost. Provided the bidder is qualified, the bid with the lowest evaluated price, but not necessarily the lowest submitted price, is likely to be successful.

5. The bid price read out at the bid opening shall be adjusted to correct any arithmetical errors. Also, for the purpose of evaluation, adjustments shall be made for any quantifiable nonmaterial deviations or reservations. Price adjustment provisions applying to the period of implementation of the contract shall not be taken into account in the evaluation.

6. For goods and equipment, nonprice factors that normally may be taken into consideration include payment schedule; delivery time; operating costs; efficiency and compatibility of the equipment; availability of service and spare parts; and related training, safety, and environmental (including sustainability) benefits. In particular circumstances (e.g., high-level technology), such nonprice factors may include, among others, technical quality, life cycle costing, long-term maintenance, and use of alternative technologies.

7. Factors other than price shall, to the extent practicable, be expressed in monetary terms in the evaluation provisions of the bidding documents or be given a relative merit weight if it is not possible to express them in monetary terms for demonstrable reasons.

8. Under works contracts, contractors are responsible for all duties, taxes, and other levies, and bidders shall take these factors into account in preparing their bids. If time is a critical factor, the value of early completion to the borrower may be taken into account according to criteria presented in the bidding documents. 


\section{Evaluating Consulting Services}

9. Under the quality- and cost-based selection (QCBS), the public opening of the bidders' financial proposals is held following completion of the technical evaluation. During this opening, the name of the firms, the technical quality scores, and the proposed prices are announced and recorded. The borrower then reviews the congruency of the technical and financial proposals, makes adjustments as appropriate, and corrects arithmetical or computational errors. The total score is obtained by weighting and adding the technical and financial scores; this determines the overall ranking of the consultants' proposals before contract negotiations. The weight for the cost is chosen, taking into account the complexity and impact of the assignment and the relative importance of quality.

10. Under the quality-based selection (QBS), price will not be used as a selection criterion; the bidding documents request firms to submit a technical proposal only. Using methodology and criteria as in QCBS for the evaluation and ranking of the consultants' technical proposal, the borrower requests the consultant with the highest ranked technical proposal to submit a detailed financial proposal for negotiation, including supporting documentation that may be subject to audit.

11. When the borrower applies the consultants' qualification selection (CQS), it selects the firm with the most appropriate qualifications and references meeting the stated requirements of experience and competence relevant to the assignment from the information provided by firms in response to the relevant request for expression of interest. The selected firm is then asked to submit a combined technicalfinancial proposal and then invited to negotiate the contract.

12. When fixed-budget selection (FBS) is the selected method, firms submit their best technical and financial proposals in separate envelopes, at the same time, and within the budget. Evaluation is done based on the indication given of the available budget and of a minimum qualifying mark for the quality (usually 750 points out of a possible 1,000 points). Following the first evaluation of all technical proposals, the financial proposals of firms meeting the minimum qualifying mark will be opened in public and prices announced. Proposals that exceed the indicated budget are rejected and the consultant who has submitted the highest ranked technical proposal among the remaining proposals will be selected and invited to negotiate. 
13. For the least-cost selection (LCS) method, firms are requested to submit technical and financial proposals in separate envelopes at the same time. The bidding documents would define the minimum qualifying mark for the quality (normally 750 points out of a possible 1,000 points). Technical proposals are opened first and evaluated. Those securing less than the minimum qualifying mark are rejected, and the financial proposals of the rest are opened in public.

The firm with the lowest price is then selected and invited to finalize the contract.

14. LCS may also be used for selecting consultants for smaller assignments of a standard or routine nature (audits, engineering design and/or supervision of simple projects, and simple surveys) where well-established practices and standards exist.

15. The evaluation procedures for selecting individual consultants are simpler and quicker than those for selecting consulting firms. Individual consultants are recruited on the basis of their qualifications and experience for the assignment. When the borrower recruits individual consultants for loan projects, agreements are reached on the type of consultant best suited for the assignment, and the applicable procedure. 


\section{APPENDIX 6}

\section{Asian Development Bank Review of Procurement Decisions}

1. To ensure that funds are used only for the purposes for which the financing was granted, the Asian Development Bank (ADB) carries out a review of procurement using a risk-based approach through prior and post review (sampling).

2. The determination of whether a procurement process is subject to prior or post review (sampling) is based on the project and activity-specific procurement risks, which are assessed during project preparation and reassessed and updated during project implementation.

The requirement for prior or post review (sampling) is specified in the procurement plan.

3. During project implementation, ADB monitors and reassesses the risk and risk mitigation measures, and may require the borrower to revise the prior or post review (sampling) requirements in the procurement plan.

4. Procurement oversight under alternative procurement arrangements is based on a trust-and-verify approach and may rely on oversight mechanisms of the borrower or those agreed in the applicable financing or other agreements.

\section{Scheduling of Procurement}

5. ADB reviews the procurement arrangements proposed by the borrower in the procurement plan for its conformity with these Regulations. The procurement plan covers an initial period of at least 18 months.

6. The initial procurement plan and any subsequent version will be prepared by the borrower and agreed with ADB. The borrower shall update the procurement plan annually or as needed, covering each 
successive 18-month period of project implementation. ${ }^{1}$ The initial procurement plan and any subsequent revision will be agreed with ADB.

\section{Prior Review}

7. High-risk contracts as identified in the procurement plan are subject to ADB's prior review. The borrower shall make such additions or modifications to, or deletions from, the documents reviewed as ADB may request.

8. Prior review requirements typically are as follows:

(a) In cases where prequalification is used, prior review shall encompass the draft documents to be used, including the text of the invitation to prequalify, the prequalification documents, and the evaluation methodology, together with a description of the advertising procedures to be followed. The evaluation report and the list of proposed prequalified bidders shall be furnished by the borrower to ADB for its comments before the applicants are notified of the borrower's decision.

(b) Before bids are invited, the borrower shall furnish a complete set of the draft bidding documents to ADB for its comments, together with a description of the advertising procedures to be followed for the bidding and the draft invitation for bids.

(c) After bids have been received and evaluated, the borrower shall, before a final decision on the award is made and before the expiry of any standstill provision, if any, furnish ADB with a detailed report on the evaluation and comparison of the bids received, together with the recommendations for award and such other information as $A D B$ shall reasonably request.

(d) If ADB determines that the intended award would be inconsistent with the procurement plan, it shall promptly inform the borrower and state the reasons for such determination. Otherwise, ADB shall provide its no-objection to the recommendation for contract award, upon receipt of which the borrower shall promptly award the contract. 
(e) If the borrower receives protests or complaints from bidders, these will be addressed as further detailed in Appendix 7 of the Regulations.

(f) After each contract is awarded, ADB shall be furnished with copies of the contract as executed. ${ }^{2}$

(g) The borrower is required to retain all documentation related to bidding and contract implementation for at least 1 year after the project closing date.

9. In the case of contracts subject to prior review, the borrower shall seek ADB's no-objection where any modification would individually or in aggregate increase the original price of the contract by more than $15 \%$. If ADB determines that the proposal would be inconsistent with the provisions of the procurement plan, it shall promptly inform the borrower and state the reasons for its determination.

\section{Post Review (Sampling)}

10. Contracts that are not subject to ADB prior review are subject to post review using a sampling methodology by ADB that is summarized in the project procurement plan (post review sampling). The methodology is based on the value, nature, and distribution of these contracts and the procurement risks, including the capacity of the borrower. Based on the risk assessment, ADB may review the initial contract(s) as necessary. The sampling methodology should cover contracts amounting to a representative range of the total number of transactions covered by the project plan in terms of value and number, but including in the sample review of all types of contracts identified in the project procurement plan. ${ }^{3}$

11. The borrower shall retain all documentation with respect to each contract where post review (sampling) is required during project implementation and for at least 1 year after the project closing date. This documentation generally includes the bid proposals, the original signed contract, the evaluation report (including the analysis of the respective proposals), and recommendations for award, for examination by ADB or by its consultants.

Any proposed changes which differ substantially from the original draft as reviewed by ADB shall be submitted to ADB for prior no-objection.

Appendix 7, para. 15. 
12. Master copies of electronic documents must be retained in print form, suitably authenticated by the issuing agency by signature, stamp, or other feature acceptable to ADB. Alternatively, audit trails can be made available in case an electronic procurement system was used and documents are in electronic format.

13. The borrower shall furnish the required documentation to ADB soon after award of contract unless otherwise specified in the financing agreement.

14. If ADB determines that the goods, works, or services were not procured in accordance with the agreed procedures as reflected in the procurement plan, it may take appropriate actions consistent with the terms and conditions of such agreement(s) and ADB's implementation support and monitoring role. 


\section{APPENDIX 7}

\section{Bidding-Related Complaints}

\section{Purpose}

1. This appendix provides guidance on the procedures for dealing with procurement-related complaints arising out of any bidding process specifically subject to use of these Regulations. Any complaints alleging issues relating to fraud, corruption, and/or any other prohibited practice under the Asian Development Bank (ADB) Anticorruption Guidelines shall be immediately referred to ADB's Office of Anticorruption and Integrity (OAI) for investigation and resolution.?

\section{Scope}

2. A bidding process includes procurement planning; framing of specifications; terms of reference; costing; packaging; preparation and issuance of all bid-related documentation (including for prequalification or short-listing) for procurement of goods, works, and nonconsulting and consulting services; and selection, evaluation, and final notice of contract award. ${ }^{2}$

3. The procedures set out in this appendix do not apply in the case of alternative procurement arrangements. ${ }^{3}$ Under such arrangements, the applicable procurement rules and procedures may be

(a) those of another multilateral or bilateral agency or organization involved in the project (including through mutual reliance whereby such party takes a lead role in implementation support and monitoring of procurement activities), or

Para. 9 of this Appendix.

Such process does not include post-award contract signing and subsequent contract administration or management, which is subject to the terms and conditions of the legal agreement between the borrower and the bidder awarded the contract.

3 Paras. 1.9-1.10 of these Regulations. 
(b) those applied by an agency or entity of the borrower where it has been agreed by ADB.

\section{Complaint}

4. A complaint is a communication recorded in written form, including mail, e-mail, fax, or communication through an electronic procurement system (hereafter referred to as communication) submitted by an interested party to the borrower and/or ADB arising out of or relating to a specific bidding process that alleges a misapplication, or omission in application, of ADB's Procurement Policy and/or any of these Regulations amounting to a breach thereof. An interested party for this purpose is an applicant for prequalification; a party interested in bidding or expressing interest; or a bidder bidding for, proposing to bid for, or being notified of award of (including notification of intention to award) a contract.

5. In a bidding process subject to ADB's prior review, complaints shall be promptly shared by the borrower with $A D B$ to determine an appropriate course of action. In such cases, the borrower shall provide ADB with all relevant information and documentation, including a draft response to the interested party concerned, for ADB review, and any additional information that may be requested by ADB.

6. Procurement documentation as evidence or to substantiate a complaint includes, among other things, an invitation for bid; a specific procurement notice; an invitation for prequalification; a prequalification application; an expression of interest; any and all documentation constituting a bid or proposal, including but not limited to instructions to bidders; and related forms, templates, correspondence, notice of rejection of bid or proposal, notice of technical and/or financial score or evaluated bid price, and debriefing-related minutes or communications from the borrower or ADB to the bidder.

\section{Requirements for Consideration}

7. For effective and expeditious resolution, a complaint should provide the following:

(a) Basic information: The submission should include the name, contact details, and address of the interested party. The specific 
project, prior material correspondence with the borrower, and any other pertinent information should also be detailed.

(b) Stage of bidding process: The stage of the bidding process (including prequalification or short-listing) should be identified. The complaint may challenge, among other things,

(i) procurement documentation (including in connection with prequalification) and related processes and procedures, if the complaint is filed prior to bid submission;

(ii) a borrower's decision to declare the bid or proposal nonresponsive or bidder unqualified, if the borrower has made a firm decision to reject the bid or proposal or bidder in advance of contract award in accordance with applicable procedure; or

(iii) a borrower's decision to award the contract to another bidder. ${ }^{4}$

(c) Alleged inconsistency or violation: The manner in which the borrower's actions or circumstances give rise to the alleged violation of applicable procurement policy provisions and/or procedures. Any actual or potential adverse impact on the interested party should be detailed.

\section{Review Process}

8. The manner in which a complaint is reviewed, and the applicable time frame for such a review by the borrower (and, if prior review, by $A D B$ ), depends on the substance of the allegations, the stage of the bidding process to which the complaint relates, and whether the said bidding process is subject to prior or post review as set out in the procurement plan.

9. Allegations related to fraud and corruption will be dealt with in line with para. 1.33 of these Regulations.

In the circumstances set out under (b) and (c), the complaint should also reflect all relevant information provided through any related debriefing process. 


\section{A. Prior Review}

10. If the borrower receives a complaint prior to the deadline for bid submission, such receipt must be promptly acknowledged, with copies of both documents and all other relevant information and documentation promptly provided to ADB. A timely response ${ }^{5}$ (including proposed modification of the bidding documents and/or extension of deadline, if appropriate) should be drafted by the borrower for ADB's review and, after obtaining ADB's no-objection, communicated to the interested party. If necessary, the borrower may be required to issue a bid addendum.

11. If the borrower receives a complaint after the bid submission deadline but before notification of contract award, ${ }^{6}$ such receipt must be promptly acknowledged, with copies of both documents and all other relevant information and documentation provided to ADB. A timely response (including any proposed modification of the relevant bid evaluation, if necessary) should be drafted by the borrower for ADB's review and, if approved, the bid evaluation should be modified as necessary, followed by due notification of (or intention to notify) award of contract.

12. If the borrower receives a complaint after notification of intention to award in those instances in which a standstill period applies for submission of complaints (prior to expiry of the applicable standstill period), the borrower should, in a timely manner, draft a response (and, as in nonstandstill situations, propose modification of the relevant bid evaluation, if appropriate) for ADB's review and, after obtaining ADB's no-objection, notify the bidder accordingly.

13. Where the contract is subject to ADB prior review as per the procurement plan, the borrower should consult with ADB about the steps, if any, required such that the challenged bidding process may appropriately go forward while the merits of the complaint are under consideration by the borrower and ADB.

Appropriate time periods for each of the steps outlined in this appendix shall be identified in guidance notes issued by ADB for borrowers.

6 These circumstances include situations where the borrower has made a formal decision to reject a bidder as nonresponsive or otherwise disqualified in advance of any notice of intention to award, or award of, a contract in accordance with a permitted procedure. 
B. Post Review (Sampling)

14. Where the contract is subject to post review (sampling) as per the procurement plan, the borrower will take actions it considers appropriate in the circumstances to address procurement-related complaints.

15. Depending on the nature, value, extent, and frequency of occurrence of complaints relating to ADB-financed transactions that are subject to post review (sampling), ADB may take any actions to address instances of noncompliance that are consistent with the terms and conditions of the relevant financing agreement, including any contractual remedies specified therein.

16. ADB may seek modification to the procurement plan ${ }^{7}$ to reflect any one or more of the following measures, among others:

(a) new or increased targeted capacity building,

(b) change frequency of the sampling previously approved for post review, and/or

(c) introduce prior review for those categories of procurement transactions and processes previously subject to post review.

\section{Resolution}

17. A borrower should undertake a timely and considered review of the substance of any complaint filed pursuant to the terms of this appendix, including all related facts, circumstances, and documentation.

18. All outstanding issues identified in a complaint should be resolved in a timely manner so that any challenged bidding process may be corrected, if and as appropriate, and duly implemented and completed in accordance with the terms of the relevant procurement plan agreed between the borrower and ADB.

19. The response of the borrower to the allegations raised in a complaint, while ensuring appropriate confidentiality of information, should be clear and meaningful and must, at a minimum, provide a concise statement of issues for resolution, relevant facts and evidence relating to such issues, the conclusions and decisions reached, and the basis 
and rationale for such conclusions and decisions, grounded in reasoned analysis. The borrower will keep ADB duly informed and updated.

\section{Roles and Responsibilities}

\section{A. Interested Party}

20. A complaint from an interested party should be adequately supported with the necessary information and documentation to help expeditious review by the borrower. This includes submission of basic information, identification of stage of the challenged bidding process, and the alleged inconsistency or violation.

21. For efficient and effective resolution, any complaints must be submitted within the permitted time frame and to the appropriate official designated for receipt of such complaints in the relevant procurement documentation. The interested party shall make reasonable efforts to ensure that such complaint is as clear and specific as possible with respect to the issues identified for resolution.

\section{B. Borrower}

22. The responsibilities of the borrower for addressing all complaints include

(a) providing timely and sufficient information to bidders regarding the bidding process, and applicable borrower decisions in connection therewith, to allow the interested party to make an informed decision about whether filing a complaint is appropriate in the circumstances;

(b) acknowledging receipt, and undertaking timely review, of any complaint, including providing the interested party concerned with due opportunity, as circumstances may require, to explain or clarify any unresolved issues arising out of such complaint;

(c) resolving complaints fairly, impartially, and promptly;

(d) preserving the confidentiality of the procurement and any related complaint process, including any proprietary commercial or financial information and/or trade secrets so identified in the bidding or proposal documentation; 
(e) maintaining complete records of all complaints and their resolution; and

(f) providing timely and complete information and documentation of any complaint submitted as and when requested by ADB.

\section{Asian Development Bank}

23. All complaints addressed to ADB will be forwarded promptly to the borrower for review and resolution. ADB will consider any remedial or other action proposed by the borrower to address the alleged impropriety or challenged action identified in the complaint. Except for acknowledging receipt of a complaint, $A D B$ does not normally directly enter into any discussion or communication with any interested party until after publication of contract award.

\section{Tracking and Reporting}

24. Borrowers are required to prepare and maintain clear and comprehensive documentation and records relating to all procurement-related complaints that are subject to the provisions of this appendix for the purpose of effective tracking, monitoring, and periodic reporting on the filing, review, and resolution of such complaints by both borrowers and ADB.

25. The use of e-procurement platforms is encouraged by ADB to ensure the highest standard of transparency, and to undertake comprehensive and reliable collection as well as timely analysis of data related to procurement complaints.

\section{Contract Administration}

26. If the related bidding process was subject to prior review, the borrower must promptly inform ADB of

(a) any disagreement or dispute arising between the parties during implementation that activates (or seems likely to trigger application of) any dispute resolution mechanism under the contract, and

(b) actions proposed by the borrower to resolve such imminent or pending dispute in a timely manner. 


\section{APPENDIX 8}

\section{Contract Management}

1. Effective contract management requires systematic and efficient planning, execution, monitoring, and evaluation to optimize performance while managing risks to ensure that both parties fulfill their contractual obligations with the ultimate goal of achieving value for money and results.

2. The borrower shall begin developing a contract as early as possible in the procurement process. As required by these Regulations, the contract conditions shall be included in the bidding document for the particular procurement process. The level of detail required in a contract shall depend on the risk and complexity of the contract, and the terms and conditions shall be fit for purpose with appropriate allocation of risks, liabilities, roles, and responsibilities of the parties.

3. A contract management plan acceptable to ADB will be developed during contract creation and completed at the time the contract is signed. Contract management considerations should be taken into account to determine the appropriate contract type and contract terms in view of the nature, risk, and complexity of the activity; fitness for purpose; and the optimal allocation of risk, liabilities, and roles and responsibilities of the contracting parties. A contract management plan will include key performance indicators and milestone events. The borrower should monitor the performance and progress of contracts in accordance with the contract management plan and provide timely reports to $A D B$.

4. Borrowers shall proactively manage each contract in accordance with the contract management plan throughout its duration, using set key performance indicators to ensure that contractor performance is satisfactory, contract requirements are met, and stakeholders are well informed and satisfied with the goods, works, and nonconsulting and consulting services provided under the contract. An evaluation of the contract performance shall be carried out at contract completion to assess the performance and, if applicable, identify any lessons learned for future contracts. 
5. Depending on the complexity, value, risk, and scope of the contract, the contract management plan shall at least include

(a) for simple and low-value contracts:

(i) key roles and responsibilities,

(ii) key contractual dates and delivery milestones,

(iii) budget and payment milestones, and

(iv) record-keeping requirements.

(b) for high-value, high-risk, or complex contracts, a summary of contract details such as

(i) identified potential risks (such as delays in the contractor's right of access to site, payment delays, and other defaults in the borrower's contractual obligations that could potentially lead to contractual disputes) and their mitigation;

(ii) key contacts, roles, and responsibilities of the parties;

(iii) communication and reporting procedures;

(iv) key contractual terms and conditions;

(v) contractual milestones including critical path (identified to ensure early detection and mitigation of issues) and payment procedures consistent with contractual provisions;

(vi) key contract deliverables, identified and properly described so they can be easily monitored and updated to account for change orders during the execution of the contract;

(vii) key performance indicators and measurement process;

(viii) contract variation control mechanisms; and

(ix) record-keeping requirements.

6. During contract execution, the borrower shall use the contract and the contract management plan to ensure that both contracting parties are complying with the contractual provisions. Monitoring shall ensure that, wherever possible, amicable resolution of contractual disputes takes place. Where that is not possible, the use of other dispute resolution mechanisms provided in the contract shall be monitored closely to ensure that resolutions are obtained in a timely manner. For large and complex contracts, the option of using expert independent and impartial third-party oversight for contract monitoring should be considered. 


\section{APPENDIX 9}

\section{Roles and Responsibilities in Asian Development Bank- Financed Procurement}

\section{Purpose}

1. This appendix provides clarity on roles and responsibilities of various stakeholders in the bidding process for procurement financed by the Asian Development Bank (ADB). Roles and responsibilities for biddingrelated complaints are defined in Appendix 7.

\section{Responsibility for Procurement}

2. The borrower prepares the procurement plan that is agreed by ADB. The borrower is legally responsible and accountable for the procurement. 'It invites, receives, and evaluates bids, and awards the contract. The contract is between the borrower and the supplier, service provider, or contractor; ADB is not a party to the contract. The responsibility for the implementation of the project, and therefore for the payment of goods, works, and services under the project, rests solely with the borrower. ${ }^{2}$

\section{Roles of the Asian Development Bank}

3. The procurement plan identifies the contracts where procurement documents are reviewed by ADB prior to their issue, as described in Appendix 2. 
4. If at any time $A D B$ concludes that agreed procedures were not followed in any material respect, ${ }^{3} \mathrm{ADB}$ may declare noncompliance, as described in paras. 1.29-1.30. If a borrower has awarded a contract after obtaining ADB's no-objection, ADB will declare noncompliance only if the no-objection was issued on the basis of incomplete, inaccurate, or misleading information furnished by the borrower.

5. If $A D B$ determines that corrupt or fraudulent practices were engaged in by representatives of the borrower or of the bidder, it may impose the applicable sanctions set forth in its Anticorruption Policy (1998, as amended to date).

6. ADB has published standard bidding documents for various types of procurement, and these may be used by borrowers in accordance with the provisions of any agreed procurement plan.

7. Where during the development of the procurement plan, especially in the context of fragile and conflict-affected situations, the assessment of the implementing agency's capability to carry out the procurement or its resources and previous experience in procuring these types of activities indicate insufficient capacity to meet the challenges of the procurement without significant risk, $A D B$ may agree to provide the borrower with extended procurement implementation support. In all cases, project execution remains the borrower's responsibility and expanded implementation support does not result in ADB carrying out procurement on behalf of the borrower.

\section{Information on Bidding}

8. Information on bidding opportunities under open competitive bidding may be obtained from procurement plans and specific procurement notices. General guidance on participation, as well as advance information on business opportunities in upcoming projects, may be obtained from the ADB website. ${ }^{4}$

ADB normally undertakes annual and midterm project reviews during the course of project implementation, including coverage of project procurement-related activities.

ADB. Business Opportunities. https://www.adb.org/site/business-opportunities/main 


\section{Bidder's Role}

9. Once in receipt of the prequalification or bidding documents, the bidder should study the documents carefully to decide if it can meet the technical, commercial, and contractual conditions, and, if so, proceed to prepare its bid.

10. The bidder should then critically review the bidding documents to see if there is any ambiguity, omission, or internal contradiction, or any feature of specifications, terms of reference, or other conditions which are unclear or appear discriminatory or restrictive. In such case, the bidder should seek clarification from the borrower, in writing, within the time period specified in the bidding documents for seeking clarifications.

11. The criteria and methodology for selection of the successful bidder are outlined in the bidding documents. If these are not clear, clarification should be similarly sought from the borrower.

12. As stated in para. 1.2 of these Regulations, the specific bidding documents issued by the borrower govern each procurement transaction. If a bidder concludes that any of the provisions in the bidding documents are inconsistent with these Regulations, it should also raise such issue with the borrower.

13. It is the responsibility of the bidder to raise any issue of ambiguity, contradiction, omission, etc., prior to the submission of its bid to assure submission of a fully responsive and compliant bid that includes all the supporting documents requested in the bidding documents.

14. Noncompliance with critical requirements (technical and commercial) will result in rejection of the bid. If a bidder wishes to propose deviations to a noncritical requirement, or propose an alternative solution, the bidder should quote the price for the fully compliant bid and then separately indicate the adjustment in price that can be offered if the deviation is accepted. Alternative solutions should be offered only when authorized in the bidding documents.

15. Once bids are received and publicly opened, bidders will not be required or permitted to change the price or substance of a bid.

\section{Confidentiality}

16. The process of bid evaluation shall be confidential until the publication of contract award. This is essential to enable the borrower and ADB to avoid either the reality or perception of improper interference. 


\section{Actions by the Asian Development Bank}

17. Bidders may send copies of their communications on issues and questions with the borrower to $A D B$, or to write to $A D B$ directly, when borrowers do not respond promptly or the communication is a complaint against the borrower. All such communications should be addressed to the project officer for the project, with a copy to the director general of the Operations Services and Financial Management Department.

18. References received by ADB from potential bidders, prior to the closing date for submission of the bids, will, if appropriate, be referred to the borrower with ADB's comments and advice for action or response.

19. Communication received from bidders after the opening of the bids will be handled as follows. In the case of contracts not subject to prior review by $A D B$, the communication will be sent to the borrower for due consideration and appropriate action, if any, and these will be reviewed during subsequent supervision of the project by ADB staff.

20. In the cases of contracts subject to the prior review process, communications may be examined by ADB in consultation with the borrower. If additional data is required by $A D B$ to complete this process, such information will be promptly provided by the borrower.

21. If additional information or clarification is required from the bidder, ADB will ask the borrower to obtain and comment on, or incorporate, such additional information, as appropriate, in the evaluation report. ADB's review will not be completed until the communication is fully examined and considered.

22. Except for acknowledgment, ADB will not normally enter into discussion or correspondence with any bidder during the evaluation and review process of the procurement until award of the contract is published. Notwithstanding this, ADB may enter into discussion where it deems it necessary to conduct investigations, audit, evaluation, or other assessments of the procurement process.

\section{Debriefing}

23. If after notification of award, a bidder wishes to ascertain the grounds on which its bid was not selected, it should address its request to the borrower. If the bidder is not satisfied with the explanation given and wishes to seek a meeting with $A D B$, it may do so by writing to the 
director general of the Operations Services and Financial Management Department, who will arrange a meeting at the appropriate level and with the relevant staff. In this discussion, only the bidder's bid can be discussed and not the bids of competitors. 


\section{About the Asian Development Bank}

ADB's vision is an Asia and Pacific region free of poverty. Its mission is to help its developing member countries reduce poverty and improve the quality of life of their people. Despite the region's many successes, it remains home to a large share of the world's poor. ADB is committed to reducing poverty through inclusive economic growth, environmentally sustainable growth, and regional integration.

Based in Manila, ADB is owned by 67 members, including 48 from the region. Its main instruments for helping its developing member countries are policy dialogue, loans, equity investments, guarantees, grants, and technical assistance. 